\title{
THE POLITICS OF PRESENCE: POLITICAL REPRESENTATION AND NEW ZEALAND'S ASIAN MEMBERS OF PARLIAMENT
}

\author{
By Seonah Choi
}

A thesis submitted in fulfilment of the requirements for the degree of Master of Arts in Political Science at Victoria University of Wellington 


\section{Contents}

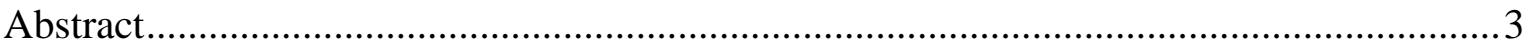

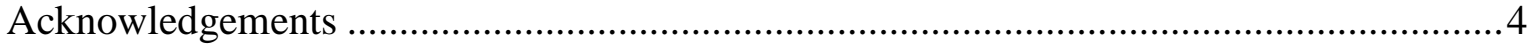

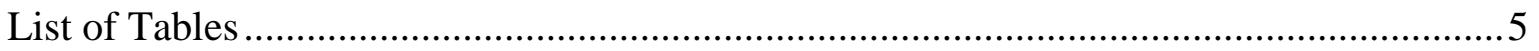

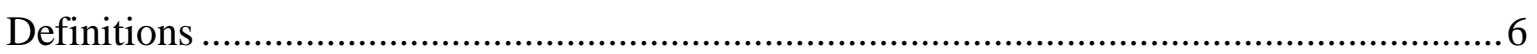

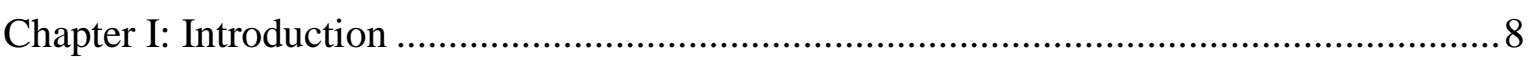

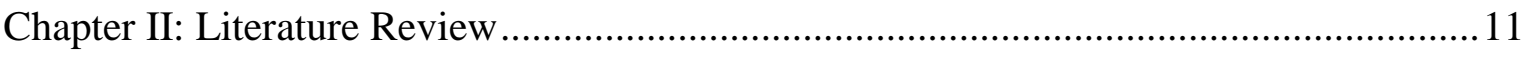

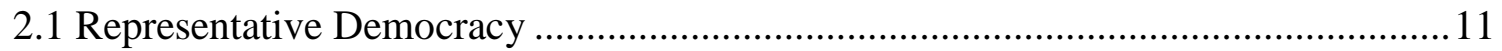

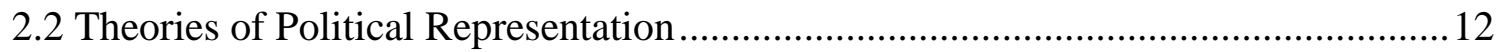

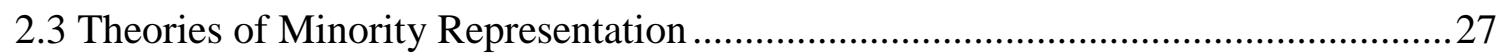

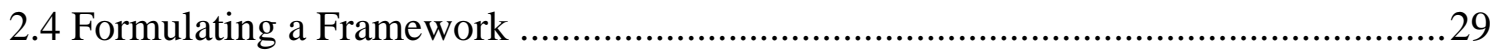

Chapter III: Electoral Reform in New Zealand: First-Past-the-Post to Mixed Member

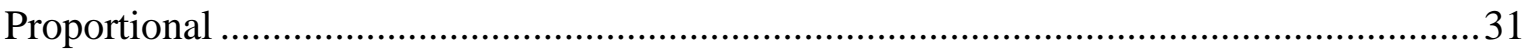

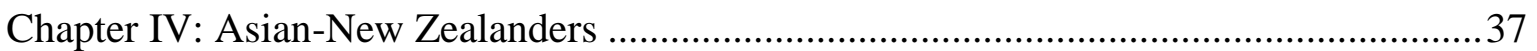

Chapter V: New Zealand's Asian Members of Parliament ................................................ 41

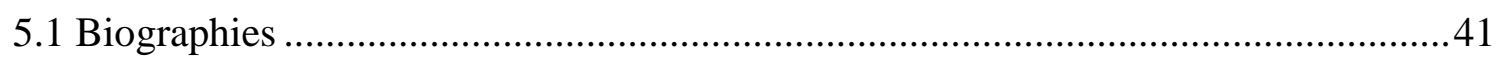

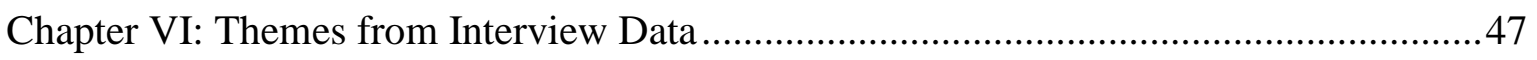

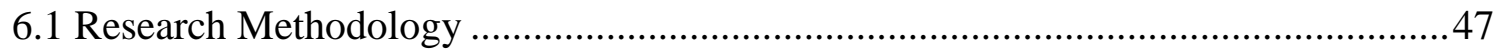

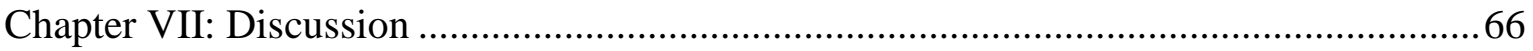

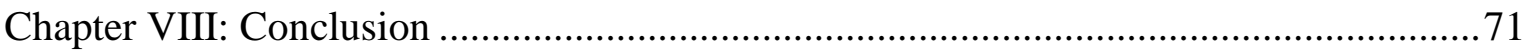

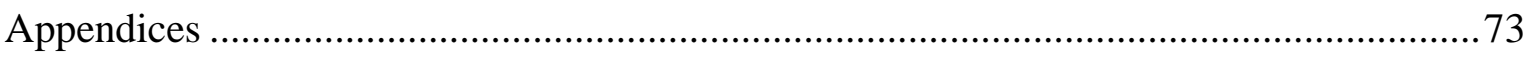

Appendix 1: Definition of the Asian ethnicity by geographic origin ...............................73

Appendix 2: Growth in New Zealand's Asian population, 1991-2006 ............................73

Appendix 3: Growth in major ethnic groups in New Zealand, 1996-2006......................74

Appendix 4: Members of Parliament identifying as Māori, Pacific peoples or Asian 1984-2008, and Mãori, Pacific peoples or Asian share of the total population ..............74

Appendix 5: Electoral Commission on the four alternative voting systems at the 2011

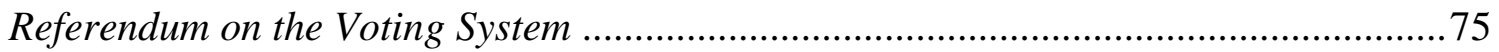

Appendix 6: Interview information provided to participants .........................................77

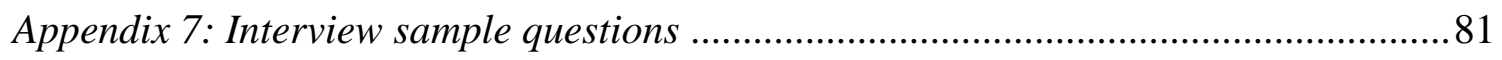

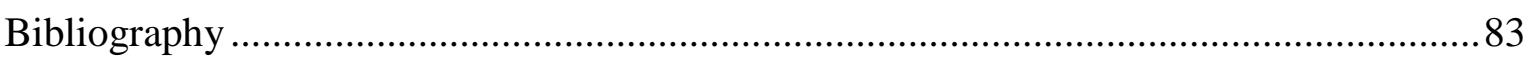




\section{Abstract}

In New Zealand, existing studies relating to the political representation of the country's minority groups are largely confined to that of women and the Māori population. Unsurprisingly then, the representation of Asian-New Zealanders is an area that has been mostly overlooked to date. However, the numerous indicators that allude to the group's growing social and demographic presence also suggests it is of increasing importance that they are included in New Zealand's political narrative.

This thesis seeks to address the gap by undertaking a case study of current and former Asian-New Zealand members of Parliament, in an attempt to establish their representative role.

The complexities of this undertaking are readily recognised. The theoretical component of this thesis draws on a number of concepts from under the umbrella of political representation. Similarly, the primary data gathered from a series of extensive interviews with the intention of supplementing the aforementioned literature review is subject to other factors, including but not limited to political structure and individual perception.

In spite of the expansive and subjective area of focus, and while only intended to be an exploratory (rather than exhaustive) work, it is hoped that this thesis will make a meaningful contribution to an understudied field in New Zealand political studies. 


\section{Acknowledgements}

I wish to thank all of those without whom this thesis would not have been possible.

Foremost, my gratitude goes to my supervisor Professor Stephen Levine. Your benevolent guidance is not limited just to this thesis; thank you for your advice and encouragement although perhaps I should be thanking you most for your patience.

I am also grateful to the University's Faculty of Humanities and Social Sciences for the provision of a research grant which enabled me to carry out the fieldwork involved in the composition of this thesis.

I thank my friends and family for their support.

I reserve my last expression of thanks for the individuals who participated in this thesis for your time, your insight and most importantly your experiences, for without them this thesis would truly not have been possible. 


\section{List of Tables}

Table 1: Results for the 2011 Referendum on the Voting System on 10 December 2011

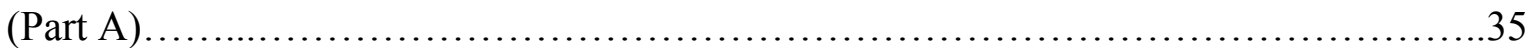

Table 2: Results for the 2011 Referendum on the Voting System on 10 December 2011

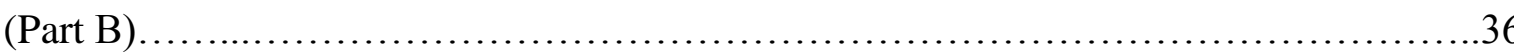




\section{Definitions}

Asian

The definition of "Asian" as referred to throughout this thesis is based on the categories used in the New Zealand census, which has been developed by Statistics New Zealand: "This group is made up of people with origins in the Asian continent from Afghanistan in the west to Japan in the east and from China in the north to Indonesia in the south" (as cited in Ministry of Health, 2012). This definition can differ from the classification used in other countries such as the United Kingdom or Australia.

\section{Ethnicity}

In its analysis of the New Zealand population, the country's national statistical office, Statistics New Zealand (Statistics New Zealand, 2005b) regards "ethnicity" as an individual's self-perceived, present-day cultural affiliations to an ethnic group. It differs from other related terms: race is a biological and ascribed characteristic, while ancestry is biological and historical, and citizenship refers to a legal status (Spoonley, 1993). Among the common traits that are regarded as contributing to an individual's identification with a particular ethnic group include religion, language, shared experiences, and common geographic or ancestral origin.

Throughout this paper, references will be made to the ethnicities of selected individuals. Given the aforementioned self-prescriptive nature of ethnicity, these references are assumptions that have been made based on public statements made by the individuals involved. Furthermore, in consideration of this paper's focus on Asian individuals, it seems necessary to circumscribe this ethnicity in particular. The subsequent effort, derived from classifications made by government agencies including the Department of Labour (Badkar \& Tuya, 2010) and Statistics New Zealand (Statistics New Zealand, 2005a), has identified the Asian ethnicity as one that can be most easily conveyed in geographic terms. Appendix 1 illustrates the "Asian" regions of origin or association that this paper assumes, and while largely in accordance with the general colloquial understanding, it is not intended to be exhaustive nor conclusive. 


\section{Minority}

In employing the term "minority," this paper acknowledges the controversial connotations associated with the term. For example, Jennifer Jackson Preece (2005) evokes issues of both institutional and cultural identity and legality in her classification of minorities as a group of people who do not belong to a political community: "Minorities are political outsiders whose identities do not fit the criteria defining legitimacy and membership in the political community on whose territory they reside" (p. 9). Hence, for clarity, this paper refers only to ethnic minorities that have been identified by a numerical criterion in the subsequent usage of the term. 


\section{Chapter I: Introduction}

Comprising 9.2 per cent of the country's total population as of 2006, the Asian ethnic group is the third largest discrete ethnic group in New Zealand after European and Māori (Statistics New Zealand, 2006). Between 2001 and 2006, the group saw an increase of almost 50 per cent, from just under 240,000 to nearly 360,000 . Based on recent demographic projections, it is anticipated that Asian-New Zealanders will make up 15.8 per cent of the population by 2026 , at an annual growth rate faster than any other ethnic group (Statistics New Zealand, 2010).

The growing significance of the Asian population in New Zealand has previously been identified as among the emerging factors affecting the country's political setting (Boston, Levine, McLeay, \& Roberts, 1996, p. 4). Despite this, and a long history of settlement the first Asian arrivals date back to the beginning of modern New Zealand history - AsianNew Zealanders have been largely absent from the political narrative in this country, or otherwise arguably marginalised as disparate from the mainstream political actors.

In 1996, Chinese-born Pansy Wong became the country's first Asian member of Parliament when she was elected as a list member for the National Party. Her entry into Parliament coincided with the first election held under the mixed member proportional (MMP) electoral system - or rather more accurately - her entry was facilitated and enabled by MMP. Wong has frequently and readily credited both MMP and her ethnicity for her parliamentary career, saying: "I state quite openly that without MMP, it is unlikely that I could enter Parliament... I'm always quite clear that I entered politics because I'm an ethnic minority" (as cited in Hewitson, 2007; Wong, 2009).

Wong's assertions lend to the basis and motivation of this thesis, and they are compounded by colloquial evidence that suggest compatible attitudes are held by other actors in the political setting in New Zealand. For instance, New Zealand First Party leader Winston Peters famously described Wong as a "token" member (Herald staff, 2008b). Meanwhile, one prominent academic of Asian studies in New Zealand, Manying Ip, has alluded to the political purpose behind the inclusion of Asian candidates when she remarked that parties used Asian candidates as "poster boys or poster girls" in an attempt - at least in part - to court the vote of New Zealand's Asian population. She was disparaging of the practice, 
stating that it was misleading to "have [an Asian] put there for decoration" (as cited in $\mathrm{Ng}$, 2005). Similarly, Raymond Miller (2004) asserted that Asian members of Parliament who have recently entered Parliament were chosen primarily because they were deemed to be “mouthpieces for significant ethnic groups" (p. 86).

Such attitudes are not limited to only politicians or commentators, with political parties themselves displaying an on-going preparedness to utilise the ethnicity variable for their electoral advantage. For example, in the months preceding the general election in 2008, there was reputedly an "unprecedented focus on the "ethnic vote"" (Chambers, 2009, p. vii), with both Labour and National each holding their first "ethnic campaign launches," and National even hosting a dinner with its ethnic candidates to emphasise its diversity (Nelson Mail staff, 2008; Tan, 2008).

In light of this, this thesis is interested in identifying the political role that is assumed by Asian members of Parliament in New Zealand.

\section{Thesis Outline}

This thesis can be divided into three parts. The first part comprises of four chapters, including this introductory one, and these provide the relevant context in which to consider the original research that follows.

Each chapter in this first part surveys a different component in the study of New Zealand's Asian members of Parliament. It begins with the construction of a theoretical framework a significant undertaking given the manner in which this topic transverses existing studies of political and minority representation. This is succeeded by chapters that provide brief histories of electoral reform and the settlement and growth of the Asian population in New Zealand. In doing so, they are expected to establish the local context, and accordingly, the traits that distinguish this study from others also concerned with representation.

The second part of this thesis presents material predominantly gathered from primary sources, beginning with the biographies of each of the past and present Asian members of Parliament in New Zealand. The main body of this section is made up of responses from a series of in-person interviews with a combination of past and present these members, as 
well as senior officials from a selection of the political parties they represented or currently represent. The interviews involved questions that were aimed at determining the political role and space occupied by Asian members of Parliament in New Zealand. In the case of the members, their responses are expected to describe the role and space they identified for themselves, while in the case of the officials, their responses are more likely to describe the role and space the members are ascribed by third parties - namely the political parties, which represent a significant structural factor in New Zealand politics.

The third part of the thesis is found in the final chapter, which seeks to reconcile what has been presented in the chapters before it. It will seek to determine whether the theories of political representation align with the case study selected for this thesis - New Zealand's Asian members of Parliament - and in turn, how the findings from the case study might help to further develop these theories.

Given the reliance of this thesis on self-reported data, it is important to acknowledge the limitations of the findings it may deliver. Much of the answers provided by the participants in the interviews would have been shaped by individual perception - a highly irregular variable - that will invariably have affected their approach and response to any given question. However, by bearing this limitation in mind, it is expected that this thesis will still be successful in deriving considerable value from the interviews - albeit not by delivering definitive conclusions, but rather by offering a better understanding of some of the individuals and factors involved.

Lastly, it is important to note that this thesis is an exploratory work, and is by no means intended to provide and exhaustive explanation of the topic. Nonetheless, it is hoped that this thesis will assist in encouraging and prompting further research, and that in the course of this, a meaningful contribution will be made to an understudied - but no less important - field in New Zealand political studies. 


\section{Chapter II: Literature Review}

\subsection{Representative Democracy}

When attempting to make any measure of contribution to the topic of political representation, one must acknowledge the volume of work that has already been undertaken in this field. The following chapter is an overview of some of those works; it is intended to provide the theoretical framework within which this thesis will be constructed.

Often, the terms "democracy" and "representation" are used and subsequently understood as though they are interchangeable, and that to invoke one is to invoke the other. In modern political studies, a democratic system of government is generally accepted as an ideal, and a representative government is usually regarded as a requisite feature of a democratic state (Eccleshall, Geoghegan, Jay, \& Wilford, 1984, p. 155).

However, it is important to recognise that there are two basic types of democracy "representative democracy" and "direct democracy" - and that where the terms democracy and representation appear synonymous, it is generally the former - representative democracy - which applies.

The research aims of this thesis are concerned with the norms appropriate of a representative government. Therefore, it is assumed for the purposes of this thesis that representative democracy is normative. This clarification is necessary because representative democracy and direct democracy share different relationships with the concept of representation.

Taken in full, democracy is a large umbrella term. From a rhetorical perspective, the term draws its origins from the Greek work demos (meaning "people") and kratos (meaning "power). Subject to common usage from the fifth century onwards, it is usually translated as "people power" (Caton, 2001, p. 268; Pettit, 2009, p. 61), or that "the people hold political power" (Mezey, 2008, p. 1).

One of the first practical manifestations of democracy took place in the Greek city of Athens between $508 \mathrm{BC}$ and $322 \mathrm{BC}$. Under Athenian democracy, all male citizens were 
permitted to partake in a regular gathering called the "Assembly of the Demos," where they listened to, discussed and voted on decrees relating to all aspects of Athenian life "both public and private, from financial matters to religious ones, from public festivals to war, from treaties with foreign powers to regulations governing ferry boats" (Blackwell, 2003).

The system of Athenian democracy is oft-regarded by proponents of direct democracy as an ideal because it allows all defined citizens to participate in the state's decision-making process. As Nadia Urbinati (2006) explains, such proponents "disdain representation because it justifies a vertical relation between the citizens and the state" and in doing so promotes "a passive citizenry and an elected aristocracy" (p. 17). In resuming a rhetorical perspective, indeed, a basic interpretation would suggest representation can be understood as the act of "re-presenting, to make present again [and] that of stand for" (Prendergast, 2000 , p. 5) and that in turn, fundamentally, representation incurs an inevitable "indirectness" - a trait which Urbinati notes as one which "has never enjoyed much currency in democratic theory" (2006, p. 17).

Representative democrats, however, cite the complexities in even attempting to implement such a system, namely in the modern political context, and accordingly consider representation as a practical form of democracy.

The focus of this literature review is on what occurs with a representative government. It proceeds on the premise that the distinction between a direct democracy and a representative democracy is not as simple as one between true democracy and some vague approximation, but a more nuanced distinction between contending proposals for the implementation of democracy. It assumes that representative democracy is the both the normative and foremost institutional framework in realising the ideal of giving kratos to the demos.

\subsection{Theories of Political Representation}

While not a new concept, political representation and the complexities associated with it have continued to elude unanimous definition - with its at times contentious relationship with democratic theory forms just one idea of dispute. 
In an effort to organise the myriad of divergent understandings, Hanna Fenichel Pitkin (1967) proffers a metaphor, in which the concept is regarded as "a rather complicated, convoluted, three-dimensional structure in the middle of a dark enclosure." Existing theories of representation provide what Pitkin describes as "flash-bulb photographs of the structure taken from different angles." But each contending author, she states, "[treats] his partial view as the complete structure" (p. 10). In order to discern an accurate and complete understanding of this mysterious structure then, it is necessary to "determine from which angle each [photograph] was taken to reconcile the difference and to sort out a theorist's extrapolation from his original photograph (p. 11).

Pitkin is regarded as among the primary authors on the topic from the contemporary period. But as her introductory comments suggest, her study of representation has been well-preceded.

For instance, the Magna Carta - or the "Great Charter" - of 1251 is recognised as one of the most important documents of medieval England for its precursory role in the development of modern liberal democracy and constitutional law in today's Englishspeaking countries. The Charter limited the powers of the monarch and provided basic legal rights to all free men of England (non-serfs), as well as serving as the origin of the principle of "no taxation without representation" (Holt, 1974; Howard, 1998; U.S. National Archives and Records Administration, n.d.).

This went on to become a popular slogan during the American Revolution, for it articulated a primary grievance of the British colonists who felt their lack of direct representation in the British Parliament was a denial of their rights, and that therefore the laws passed by the Parliament were unconstitutional (J. C. Miller, 1943). Around the same period, representation became subject to increasing scholarly consideration, predominantly among American and European thinkers and philosophers.

The section below examines the "flash-bulb photographs" taken by some of these authors, from the end of the medieval period, to the Age of Enlightenment and the American Revolution, up to the present period. 


\section{Thomas Hobbes}

For his work in Leviathan (1651), Englishman Thomas Hobbes is frequently credited for providing one of the first and still-enduring discussions about political representation and in doing so, modernising the concept from its medieval roots (Runciman, 2009; Skinner, 2005).

Hobbes' contribution to the topic originates from his theory of the social contract. In Leviathan, he wrote of the "state of nature" - the way of life in the absence of civil society and a recognised authority - which he illustrated as a "war of all against all." In these anarchic conditions, there is no mutual trust, he posited; every man lives in constant struggle for survival against another. As such, life in the state of nature was "solitary, poor, nasty, brutish and short" (p. 56).

According to Hobbes, a social contract was the result of man's self-interest and rationality, which would see him conceding some of the rights he held in the state of nature (for example, the right to kill another man) in return for others doing the same. This resulted in the establishment of a sovereign, an entity superior than any man and which had the authority to enforce the social contract. All men entering into the contract to escape the state of nature would agree to submit to this authority. In reciprocation, the sovereign would be entrusted to carry out actions "expedient for their peace and common defense" (p. 76). Effectively, the sovereign was empowered to act as the men's collective representative:

\footnotetext{
"A commonwealth is said to be instituted, when a multitude of men do agree, and covenant, every one, with every one, that to whatsoever man, or assembly of men, shall be given by the major part, the right to present the person of them all, that is to say, to be their representative; every one... shall authorize all the actions and judgements, of that man, or assembly of men, in the same manner, as if they were his own, to the end, to live peaceably amongst themselves, and to be protected against other men" (p. 76).
}

As a representative, the sovereign was bound to action which ensured "peace and common defense," or in other words, the interests of its constituency (the men who have entered into the social contract). The constituency, on the other hand, was "bound not to hinder those to whom such right is granted" (p. 59). 
In summary, Hobbes' proposition sees man concede his rights to the sovereign and accord it the authority to become his representative. The sovereign in then permitted to make decisions for the communal benefit of its constituency that the men are obliged to observe and respect. However, Hobbes provides no clarity on how the aforementioned communal benefit - or "peace and common defense" - might be determined or assessed, nor whether either party - the sovereign or the men - is able to terminate the social contract at any point.

\section{John Locke}

Hobbes' fellow English philosopher John Locke also used conceptualisations of a state of nature and a social contract to construct his contribution to the subject of representation in Two Treatises on Government (1689).

However - at least relative to Hobbes' view - the state of nature Locke imagined was peaceful. While men were at liberty to live their lives as they wished, free from interference and in the absence of a sovereign or a civil authority, they were bound by the "Law of Nature" not to harm others in respect of their "life, health, liberty or possessions" (p. 123). The Law of Nature, Locke said, was predicated by God and as such, he assumed that men would abide by it. Locke's state of nature, therefore, was less the grim and dire state of war that Hobbes theorised; unlike the anarchic state Hobbes described, Locke believed in that men in the state of nature, to some extent, would be governed by a natural law and abide by it.

Men entered into a social contract, according to Locke, for further protection of their rights. While they may be bound not to harm one another in respect of the aforementioned rights by the Law of Nature, without a government to enforce this convention they were still expected to continue to live in fear. By transferring their right to uphold the Law of Nature to a central government, they would be guaranteed a "neutral judge" that existed to protect and ensure their welfare - a representative that protected their basic rights.

Locke's theory of representation also differs from Hobbes' in that Locke apportions considerable significance to accountability. The government is tasked with "the right of making laws... for the common good," and any breach of this means the constituency may 
revoke their authority, for the government derives its "powers from the consent of the governed" (p. 87). According to Locke, a government's legitimacy was drawn from its constituency and, unlike Hobbes, he argued for a mechanism that allowed for the constituency to recall the government, should it fail in its responsibilities.

\section{Jean-Jacques Rousseau}

From early on, the concept of representation was not without its critics. Swiss-born French philosopher Jean-Jacques Rousseau rejected the notion of representation, saying in The Social Contract (1762): "The instant a People gives itself Representatives, it ceases to be free; it ceases to be" (p. 115). Rousseau believed that in voting for representatives, one would in fact be enslaving oneself to the will of others.

Rousseau shared with Hobbes and Locke the premise that civil authority was not an original part of the natural relationship that existed between men in the state of nature; he too regarded it as something that was created by men. However, Rousseau diverges from Hobbes and Locke in his conviction that installing a civil authority through representation would mean to lose the connection men had with their own creation, by taking the power behind it and transferring it to a third party that appropriated their collective identity while claiming merely to reflect their views. Herein the basis of Rousseau's objection can be found; he believed that representation created the illusion that men were free when in fact they were vesting themselves to another.

Nonetheless, Rousseau argued for some kind of political society. He coined the term volonté générale, or the "general will," - the embodiment of the well-being and good of the constituency as a whole, rather than individual interests:

\footnotetext{
"There is often a great deal of difference between the will of all and the general will. The latter only looks to the common interest; the former considers private interest and is only a sum of private wills. But take away from these same wills the pluses and minuses that cancel each other out, and the remaining sum of the differences is the general will" ( $p$. 146).
}

Rousseau drew a distinction between sovereignty and government using the idea of the "general will." The sovereign, he said, would promulgate laws that were an expression of 
the general will," while the government had a more limited role in applying the laws to specific cases.

\section{John Adams}

One of the Founding Fathers, John Adams was the second president of the United States and among the first American thinkers to conceive of a representative system of government. His writings on the topic are found in Thoughts on Government (1776), a document written in response to a pamphlet written by Thomas Paine which challenged the authority of the British Government and the royal monarchy (Independence Hall Association, 2014).

Adams' conception of a representative system was grounded in his belief that direct democracy was not a feasible arrangement. "In a large society inhabiting an extensive country," he said, "it is impossible that the whole should assemble to make laws" (p. 86).

Therefore, he proposed deputising the "power from the many" to a smaller group of representatives - one which he described as "the most wise and good." For Adams, it was of great importance that this group of representatives was "in miniature, an exact portrait of the people at large" (p. 86).

\footnotetext{
"That it may be the interest of this Assembly to do strict justice at all times, it should be an equal representation, or in other words equal interest among the people should have equal interest in it" (p. 86).
}

Adams believed that the representative body "should think, feel, reason, and act" like the individuals it represented. This, and his idea that a representative should be of a superior intellect that those he represented went on to be further explored by other authors.

\section{James Madison}

For his instrumental role in the drafting of the United States Constitution, James Madison has been referred to as the "Father of the Constitution." Madison was also involved in the movement thereafter; together with Alexander Hamilton and John Jay, he authored The Federalist Papers (1788), a series of 85 articles that promoted the ratification of the draft Constitution. 
Madison's view of representation and resulting system of government was influenced by the risk he perceived to be found in factions. A faction, he explained, is a group of men "united and actuated by some common impulse of passion, or of interest, adverse to the rights of other citizens, or to the permanent and aggregate interests of the community" (p. 72). The causes of factions, he added, was "sown in the nature of man" (p. 73). While a faction that comprises a minority of a society is not of a great concern, Madison believed that if a faction grew into the majority, this posed a threat to society at large.

As a solution, Madison proposed a system of government to temper the effects of such factions - a popular government over a sizable territory instilled by representation. Madison was deliberate in stipulating the size of the territory, because the larger the area concerned, the greater diversity in passions or interests, and accordingly, the more difficulty it would be for a majority to form around an extreme view. Madison described representation as the means to "refine and enlarge public views, by passing them through the medium of a chose body of citizens," and in doing so provided some circumscription to the role of a representative. Of it, he wrote that representatives - "whose wisdom may best discern the true interest of their country, and whose patriotism and love of justice, will be least likely to sacrifice it to temporary or partial considerations" (p. 76) - had a duty to ensure that "reason, justice, and truth... [had] authority over the public mind" (p. 382) for there was "respect due from the government to the sentiments of the people" (p. 383).

\section{Edmund Burke}

Edmund Burke (1854) was a British member of Parliament as well as an author and a theorist. Burke provided a depth to the discussion of political representation with his conception of the "delegate" and "trustee" representative models.

The first of these supposed that constituents elect a representative to assume the role of their "delegate": whose function is to act as a conduit for their will. The delegaterepresentative has no autonomy from the constituency - only representing their wishes and under this model, he is given no capacity for acting in his own conscience.

“[The constituents'] wishes ought to have great weight with him; their opinion, high respect; their business, unremitted attention. It is his duty to sacrifice his repose, his 
pleasures, his satisfactions, to theirs; and above all, ever, and in all cases, to prefer their interest to his own" (p. 179).

In contrast, the second model - the trustee model - allows a representative sufficient autonomy to act in favour of the common good and the national interest in circumstances where they may conflict with the short-term wishes of his constituency:

“... [Parliament] is a deliberative assembly of one nation, with one interest, that of the whole; where not local purposes, not local prejudices ought to guide, but the general good. [...] If the local [constituency] should... form an opinion... evidently opposite to the real good of the rest of the community, the [representative] ought to be as far, as any other, from any endeavour to give it effect" (p. 180).

Burke continued on to add that while a representative must accord importance to the will of his constituency - "[the opinion] of constituents in a weighty and respectable opinion, which a representative ought always to rejoice to hear, and which he ought always most serious to consider" (p. 180) - it is his own to which a representative must give precedence: "[...] Authoritative instructions; mandates issued, which the member is bound blindly and implicitly to obey, to vote, and to argue for, though contrary to the clearest conviction of his judgment and conscience, - these are things... which arise from a fundamental mistake of the whole order and tenor of our constitution" (p. 180).

A representative, according to Burke, "owes" to his constituency "his judgment," and he himself expressed a preference for the trustee model over the delegate model, reasoning that the constituency, or the opinion-holders at large lacked the information and understanding of issues that confronted the representative, or the decision-maker:

"If government were a matter of will upon any side, yours, without question ought to be superior. But government and legislation are matters of reason and judgment, and not of inclination; and what sort of reason is that, in which the determination precedes the discussion, in which one set of men deliberate, and another decide; and where those who form the conclusion are perhaps three hundred miles distant from those who hear the arguments?” (pp. 446-448). 
A considerable amount of the debate that persists in the present day over the role of a representative can be reduced to the juxtaposition found in Burke's delegate and trustee models.

\section{John Stuart Mill}

John Stuart Mill was a British philosopher and economist and another champion of the trustee model - arguably a more strident one than Burke. In his view, presented in $O n$ Liberty (1861), a representative of the delegate model whose function is limited to merely conveying the will of his constituency (and not his own conscience), had the character of a "steam-engine":

\footnotetext{
"A person whose desires and impulses are his own... is said to have a character. One whose desires and impulses are not his own, has no character, no more than a steam engine has a character" (p. 35).
}

Mill went further by applying the condition of "superior knowledge" in order for a representative to be able to justify his trustee role. A constituency could not be "expected to postpone their particular opinions, unless in order that they may be served by a person of superior knowledge than their own," he reasoned. Once the constituency had elected a representative "wiser" than themselves, however, he urged that they "consent to be governed according to that superior wisdom."

Mill identifies this "deference to mental superiority" on the part of the constituency as a "requisite" to a healthy representative government.

\footnotetext{
"Individuals, and peoples, who are acutely sensible of the value of superior wisdom, are likely to recognize it, where it exists, by other signs than thinking exactly as they do, and even in spite of considerable differences of opinion: and when they have recognized it they will be far too desirous to secure it, at any admissible cost, to be prone to impose their own opinion as a law upon persons whom they look up to as wiser than themselves"
}

Nonetheless, Mill does little to detract from the importance with which Burke treats the will on the constituency, urging them to elect "no one who is not or at least who does not profess to be, the image of their own sentiments, and will continue him no longer than 
while he reflects those sentiments in his conduct." In turn, representatives should "make themselves as like to it as possible" (pp. 179-180).

The value that Mill places on "superior wisdom" cannot be understated, as he goes on to propose that the opinions of "persons of a more educated class" should be given "greater weight than those of the less educated" (p. 180).

\section{Hanna Fenichel Pitkin}

As previously stated, Hannah Fenichel Pitkin is credited as the author of "one of the most comprehensive discussions on the concept of political representation" (Dovi, 2011) and in fact, her efforts in The Concept of Representation (1967) not only expounds the arguments advanced by the preceding scholars, but it also provides its own original insight.

Pitkin introduces four theories of representation: 1) formalistic representation; 2) descriptive representation; 3) symbolic representation; and 4) substantive representation. These four theories, she adds, are connected and therefore it is necessary to first understand each of them in order to understand their effects.

\section{Formalistic Representation}

This theory is made up of two views: 1) the "authorisation" view; and 2) the "accountability" view. Both components are concerned with the institutional arrangements that facilitate instances of political representation.

According to Pitkin, the authorisation view - which Pitkin bases on Hobbes' work "defines representation in terms of the giving and having of authority," and the representative thereby is "someone who has been authorized [sic] to act" ( $p .38)$. The nature of these terms (namely "authorisation" and the depicted act of giving authority before representation can begin) means that representation is a "transaction that takes place at the outset, before the actual representing begins."

The authorisation view provides no scope for evaluating the performance of a representative. In fact, performance becomes a redundant point: "There is no such thing as 
the activity of representing or the duties of a representative; anything done after the right kind of authorization [sic] and within its limits is by definition representing" (p. 39).

Pitkin goes on further to explain that it would be impossible for a representative under this view to represent well, just as it is for him to represent poorly, so long as he remains within the parameters of what he has been authorised to represent. Representation, then, can be likened to a "black box" which is shaped by the initial giving of authority. Within the box, the representative can do as he pleases, and if he leaves the box, he is simply no longer representing.

Pitkin criticises the authorisation view by dismissing its assumption that authority maintains a constant relationship with representation. "Authority over others," she explains, "... is one thing; representation is another. Sometimes the two go together, but at other times they do not."

Some representatives have authority over those they represent, she admits, and often the represented may have authority over their representative; she cites cases where an employee may represent his corporation, or a servant may represent his master as examples of the latter. Similarly, it is possible to have authority over others without representing them, in the way - for example - "an army officer has authority over his men and can issue demands binding on them, but he is not thereby their representative" (p. 53).

Pitkin summarises the shortcomings of the authorisation view by stating: "[The] view makes it impossible to speak of the obligations of a representative as such, or to judge his actions in relation to his role" (p. 55).

In contrast, from an "accountability" view, the representative is someone "who is to be held to account, who will have to answer to another for what he does." While the authorisation view treats the representative as free and his constituency as bound (to the representative's will, insofar as he is authorised to act), the premise of the accountability view is the opposite. The difference between the two views is demonstrated as follows: 
"For the [authorisation view], being a representative means being freed from the usual responsibility for one's actions; for the [accountability view], being a representative means precisely having new and special obligations" (p. 55).

Thus, whereas the authorisation view would consider an election as the giving of authority by the constituency to the representative, the accountability view considers an election as a holding-to-account - "an elected official is a representative because... he will be subject to reelection or removal at the end of his term" (p. 56).

The view is focused on coaxing a certain type of behaviour from a representative, a feature its theorists see as a fundamental omission in the authorisation view. If a representative is held responsible, it is implied that he will act responsibly. While it may identify some of the controls present in a normative instance of representation, the problem with the accountability view, however, is that it effectively defines representation as "action for which one will be held to account."

Little is given to the form or the manner of the aforementioned action. "On the basis of such a definition," Pitkin points out, "a representative who acted in a completely selfish and irresponsible manner could not be criticized [sic] so long as he let himself be removed at the end of his term" (p. 58).

Pitkin rightfully assesses both the authorisation and accountability views as "empty of substantive content" (p. 58):

\footnotetext{
"Where the one group defines a representative as someone who has been elected (authorized), the other defines him as someone who will be subject to election (held to account). Where the one sees representation as initiated in a certain way, the other sees it as terminated in a certain way" (p. 55).
}

Essentially, neither view provides any insight into what occurs during representation, nor do they set out how a representative should act or what he is expected to do. 


\section{Descriptive representation}

Descriptive representation is the classification Pitkin gives to the view of scholars and theorists of representation who focus on a particular composition of a given legislative assembly:

\footnotetext{
"True representation, these writers argue, requires the legislature be so selected that its composition corresponds accurately to that of the whole nation; only then is it really a representative body" (p. 60).
}

This evokes John Adams' earlier call for a representative body to be a miniature of society at large. Descriptive representation, Pitkin says, is very different to both views of formalistic representation:

\footnotetext{
"For these writers, representing is not acting with authority or acting before being held to account [as the authorisation and accountability views promote, respectively], or any kind of acting act all. Rather, it depends on the representative's characteristics, on what he is or is like, on being something rather than doing something. The representative does not act for others; he 'stands' for them, by virtue of a correspondence or connection between them, a resemblance or a reflection" (p. 61).
}

The rationale behind descriptive representation is found in the belief that a representative who shares the traits of his constituents will also share their view, and a grouping of such representatives will act as a sample of the population at large: "A typical farmer - one who owns an average farm, who farms it as most farmers do, who thinks along the same lines as most his fellows - might be sent to the legislature to represent a farming district. His attitude toward problems facing the legislature would be representative of the general farming attitude" (p. 76).

In considering the arguments for descriptive representation, Pitkin raises the question of what characteristics are relevant for reproduction. "Politically significant characteristics vary with time and place," she says, and cites the example of religious affiliation: "For centuries [it] was an issue suitable for warfare and revolution, but has become relatively unimportant today" (p. 87). 
Pitkin regards descriptive representation as a partial view: "[... It] may be a good idea to insist that a man who can make commitments in your name should resemble you, but aside from that practical consideration his authority to make those commitments has nothing to do with representing." She expands the factors that need to be take into consideration when conceptualising political representation by saying that theorists of descriptive representation leave a void in their arguments in focusing on what a representative looks like, or is, rather than what he does as a representative: "Representing means being like you, not acting for you" (p. 89). This is significant because, as Pitkin explains, modern democracy involves more than just "being"; representative governments and the representatives they are comprised of govern - they carry out activities like "the forging of consensus [and] the formulation of policy," and descriptive representation leaves no room for traits like "leadership, initiative or creative action."

According to Pitkin, the key shortcoming of descriptive representation is that the argument that its positions representation in terms of characteristics rather than actions. She rightly makes the point that political representation consists of more than this, and cannot be satisfactorily summed up so simply.

\section{Symbolic representation}

Symbolic representation portrays representatives as symbols. Pitkin distinguishes this from descriptive representation, by analogising that symbolic representatives are to their constituency what a flag is to a nation. That is, symbolic representation "calls to mind, and even beyond that evokes emotions or attitudes appropriate to [what is being symbolised" (p. 96). "[The symbol] may well be a recognizable [sic] object, but it need not be and usually is not a representation of what it symbolizes [sic]" (p. 94). While descriptive representation is concerned with how a representative resembles those he is representing, symbolic representation is concerned with the meaning a representative has for those he is representing.

Pitkin stresses that symbols have a "vagueness, looseness... [It is] an exact reference to something indefinite. We can never exhaust, never quite capture in words, the totality of what a symbol symbolizes [sic]: suggests, evokes, implies" (p. 97). Ergo, representation is arbitrary; symbolising is not. A symbol has a meaning beyond itself - "not because of its actual resemblance of [what it refers to - that is, symbolises], not because of any real 
connection, but just because it is so considered." Pitkin provides a summary of sorts, in saying that symbolic representation exists if someone believes it does. As such, symbolic representation is based on "emotional, affective, irrational psychological responses rather than on rationally justifiable criteria" (p. 100).

Given the nature of symbolic representation then, representing in this context relies on the response a representative elicits from his constituency and the meaning he holds for them; whether the constituency believes in him, and believes that he is representing them: "The existence of representation is to be measured by the state of mind, the condition of satisfaction or belief, of... the represented" (p. 106). Symbolic representation helps to supplement the understanding of political representation as a concept by acknowledging the role of "irrational belief" in how a representative comes to represent.

\section{Substantive representation}

Here, Pitkin refers to the actions carried out by the representative, either on the behalf of or in the interests of, or as an agent of, or as a substitute for his constituency. She uses this theory to make the point that "the activity of representing as acting for others must be defined in terms of what the representative does and how he does it, or in some combination of these two" (p. 143). Arguably, this theory provides the most meaningful argument when it comes to representation, because for Pitkin, it is the very essence of political representation. It provides for the representative to act in representing his constituency, rather than simply to be or to symbolise. "Representing... means acting in the interest of the represented, in a manner responsive to them," she contended (p. 209).

Substantive representation is interested in what a representative does to effectively represent his constituency. This includes policy outcomes, preferences and actions advanced by a representative for the benefit of his constituency. It echoes the work advanced by earlier philosophers, who focused on the "collective good" and the "best interest" of the collective.

Pitkin summarises by providing a guide on how to approach the four different types of representation she has articulated with the following statement: 
"Each of the various views of representation makes some sense when applied to political life, and certain aspects of political life lend themselves to interpretation by each of the views... Each view has its particular and peculiar assumptions and implications. Think of the legislature as a pictorial representation or a representative sample of the nation, and you will almost inevitably concentrate on its composition rather than its activities. Think of the same body as a symbol and you will almost inevitably be more concerned with its psychological impact on the minds of the people than with any accuracy of correspondence between it and the nation. Think of it, in turn, as an agent or collection of agent, and your interest will focus on other concerns" (pp. 225-226).

Based on this, it can be understood that it is necessary to treat political representation as a concept made up of subsets and within a wider context in order to apply it effectively to a chosen example.

Since Pitkin, other authors have sought to define and relate political representation in more practical, rather than relatively theoretical or conceptual terms. Taking a more local view, given its pertinence to the case study which is to follow, Elizabeth McLeay (2000) sheds some light on the role of a member of Parliament in New Zealand in the absence of an official job description: "The public expects [members of Parliament] to represent the needs of their constituents and the policies of their parties. They should debate and influence policy through the legislative process, and they should monitor and scrutinise the actions of the executive. Above all, they should be responsive to the citizens they represent" (p. 215).

David McGee (2005) says of the members' role: "The office to which [they] are elected has a considerable amount of legal freedom guaranteed to it so that members themselves have the capacity to carry out the duties of the office as they see fit and indeed are able largely to define what the duties of that office are" (p. 34). This highlights the vagueness of the role of a member of Parliament, a point that is expected to be explained further in subsequent sections of this thesis.

\subsection{Theories of Minority Representation}

It has been argued that the representation of minority groups matters because it has the potential to enact far-reaching effects that extend to the basis, legitimacy and institutional 
performance of the democracy concerned, in addition to the political behaviour of both its majority and minority populations.

There are findings from research conducted overseas to support this argument. Branton (2009) analysed all elections to the United States House of Representatives between 1994 and 2004 found that "as the size of the minority population increases, the probability that a minority candidate is elected to Congress likewise increases" (pp. 459-460). Branton offers a number of explanations to account for this finding, going so far as to draw a direct causative relationship: "[Minority] candidates may be more willing to test the electoral waters in districts characterized [sic] by a large [minority] population, as this is the type of venue in which they are more likely to win" (p. 460). According to Branton, voters do in fact vote for candidates from their own ethnic group, and the presence of a minority candidate mobilises voter turnout among minority groups. On top of this, the emergence of minority candidates encourages strategic voting in majority population voters, who in the context of Branton's study recognise that "one of their own" is unlikely to win in an area with a high minority population, and therefore vote for a minority candidate who they assess to be most sympathetic to their concerns (p. 461). Branton also found consequences for prospective candidates: where odds of success were high, it was more likely "quality candidates" would continue to emerge ("For African-American quality would-be candidates, the decision to enter a congressional primary is not only based on the strength and/or presence of an incumbent but also on the African-American composition of a district"), leading to a kind of cumulative effect for minority representation (p. 461).

Studies further develop this relationship between minority candidates and minority voter behaviour. In analysing elections with African-American candidates, Griffin \& Keane (2006) found that African-American voters were more likely to vote.

Other research has found that minorities express more trust in parliaments, politicians and policies if they are represented by members of Parliament belonging to their own ethnic group. However, the "precise nature of these effects differs across countries, likely due to the particular mechanisms employed to enhance descriptive representation" (Abney \& Hutchinson, 1981; Gay, 2002). 
Joseph F. Zimmerman (1994), on the other hand, focused on the effects that the perceived underrepresentation of a given minority group could have on the given society (p. 3):

1. The lack of... members of minority groups] on governing bodies may mean that important issues receive little or no consideration during the policy-making process];

2. Minorities may become alienated from the political system and display less respect for laws enacted without their direct input by legislative bodies they view as illegitimate; and

3. The electoral system in nations with several large minority groups can promote national unity or can encourage the splintering of a nation. If a sizeable minority group is able to elect only a few or no members to public offices, pressure for secession and establishment of a new nation may increase."

These studies are not intended to be regarded as conclusive findings, but they do demonstrate in part the justification for this thesis. If overseas findings are to provide any indication, the representation of Asian-New Zealanders is an area that warrants study for the wider implications it arguably holds. While New Zealand's political context means the findings from overseas would not necessarily be replicated exactly here, they nonetheless can be expected to have some relevance. Further, the influence of context is accounted for to some extent, with later sections of this thesis giving this consideration - namely the impact of the electoral system that is now in place in New Zealand.

\subsection{Formulating a Framework}

As the survey of some of the literature around political representation plainly illustrates, there are numerous considerations that must be taken into account when making assessments of a case study, or in attempting to understand how a representative represents. The characteristics and traits of a representative, the response a representative evokes from his constituency, what activities a representative carries out to advocate for his constituency - these are all components that contribute to the complexity at hand.

Generally, in a given instance of political representation, it is possible to identify the following three components: 
1. The representing party (who is doing the representing - a political party, an elected office-holder or a representative);

2. The represented party (who is being represented - a constituency, an electorate or a group);

3. The represented idea (what is being represented - an opinion, a set of values or perspectives); and

4. The representative mechanism (how the represented idea is represented by the representing party on behalf of the represented party).

The above have been identified as aspects to representation to consider in attempting to determine the representative role that New Zealand's Asian members of Parliament assume. 


\section{Chapter III: Electoral Reform in New Zealand: First- Past-the-Post to Mixed Member Proportional}

In a representative democracy, electoral systems are the structural implement through which the constituency can express themselves. They enable the constituency to make a choice between options by casting a vote. They can also take a multitude of forms with variances between each in terms of the way votes are counted, aggregated and translated. As such, the type of electoral system that is installed in a given society has ramifications for how votes equate to seats in Parliament, the number of political parties gaining representation in Parliament, as well as the make-up of the parties themselves - all of

which have consequences for the effectiveness, accountability and stability of a government, as well as the policy-making process.

This section of the thesis seeks to illustrate how the introduction of the mixed member proportional (MMP) system, which displaced first-past-the-post (FPP), affected the entry of Asian members of Parliament in the New Zealand House of Representatives.

The first parliamentary election was held in New Zealand in 1853, with suffrage limited to men over the age of 21 who owned, leased or rented property of a certain value. Voting took place under FFP, which New Zealand had inherited from Britain following the passage of the New Zealand Constitution Act 1852.

Under FPP, voters had only one vote, which they would cast for the favoured candidate in single-member electorates. The candidate who received the highest number of votes was determined to be the winner, regardless of whether he or she had gained an absolute majority (more than half of all votes). FPP facilitated situations where one party could gain more overall votes than another, but the latter could govern by winning more seats in Parliament.

From the 1970s, during a period that was "marked by economic uncertainty" and "the emergence of new social and political movements," voters began to grow disillusioned with the two major parties, Labour and National (Electoral Commission, 2006). A 1975 Heylen Trust and Confidence poll found that 33 per cent those surveyed expressed support 
for their elected representatives; a subsequent poll saw this figure dropping to four percent by 1993 (McRobie, 1993, p. 24).

There were several reasons behind the erosion of public trust in the existing electoral system and the emergence of calls for electoral reform: the elections results in 1978 and 1981; the repeated failure of "third" political parties to achieve more than nominal parliamentary representation from voting support above 10 per cent; demands for a more representative parliament; and the perceived lack of accountability of single party government (Parliamentary Library, 2011c).

In 1985, in response to intensifying public discontent, the Royal Commission on the Electoral System was established. The Commission employed a set of 10 criteria against which to evaluate the existing electoral system and to assess alternative systems (1986, p. 11):

1. Fairness between political parties. When they vote at elections, voters are primarily choosing between alternative party Governments. In the interests of fairness and equality, therefore, the number of seats gained by a political party should be proportional to the number of voters who support that party.

2. Effective representation of minority and special interest groups. The voting system should ensure that parties, candidates and [members of Parliament] are responsive to significant groups and interests. To facilitate this, membership of the House should not only be proportional to the level of party support but should also reflect other significant characteristics of the electorate, such as gender, ethnicity, socioeconomic class, locality and age.

3. Effective Māori representation. In view of their particular historical, Treaty and socio-economic status, Māori and the Māori point of view should be fairly and effectively represented in Parliament.

4. Political integration. While the electoral system should ensure that the opinions of diverse groups and interests are represented it should at the same time encourage 
all groups to respect other points of view and to take into account the good of the community as a whole.

5. Effective representation of constituents. An important function of individual [members of Parliament] is to act on behalf of constituents who need help in their dealings with the Government or its agencies. The voting system should therefore encourage close links and accountability between individual [members of Parliament] and their constituents.

6. Effective voter participation. If individual citizens are to play a full an active part in the electoral process, the voting system should provide them with mechanisms and procedures which they can readily understand. At the same time, the power to make and unmake governments should be in the hands of the people at an election and the votes of all electors should be of equal weight in influencing election results.

7. Effective government. The electoral system should allow Governments in New Zealand to meet their responsibilities. Governments should have the ability to act decisively when that is appropriate and there should be reasonable continuity and stability both within and between governments.

8. Effective Parliament. As well as providing a Government, members of the House have a number of other important parliamentary functions. These include providing a forum for the promotion of alternative Governments and policies, enacting legislations, authorising the raising of taxes and the expenditure of public money, scrutinising the actions and policies of the executive, and supplying a focus for individual and group aspirations and grievances. The voting system should provide a House which is capable of exercising these functions as effectively as possible.

9. Effective parties. The voting system should recognise and facilitate the essential role political parties play in modern representative democracies in, for example, formulating and articulating policies and providing representatives for the people. 
10. Legitimacy. Members of the community should be able to endorse the voting system and its procedures as fair and reasonable and to accept its decisions, even when they themselves prefer other alternatives.

The report that was produced by the Commission a year later recommended the introduction of the mixed member proportional (MMP) electoral system. It concluded that of the alternative voting systems that were considered, MMP was the system that ensured fairness between parties and was likely to provide more effective representation of minority and special interest groups. It acknowledged that FPP required candidates to attain broad acceptance within an electorate in order to be successful and determined that this contributed to the under-representation of minorities, including women and ethnic groups. "The very fact that each candidate must be widely acceptable within the electorate may deter the political parties from selecting candidates belonging to minority communities," it said (Royal Commission on the Electoral System, 1986, p. 17).

The Commission expressed an expectation and a desire for "microcosmic representation" the idea that the elected body should reflect the key groups of the society that it represents. The report remarked that the current New Zealand Parliament was a "poor reflection of the community from which it is drawn" (p. 18).

Following the Commission's recommendation, a binding referendum was held in 1993 and with 54 per cent of voters indicating their favour, MMP was implemented as New Zealand's new electoral system, with the first general election was to be held under it in 1996 (Boston, et al., 1996, p. 17). Under MMP, the public is able to cast two votes: one for his or her preferred candidate for electorate MP, and one for his or her preferred party. The latter vote determines a party's total share of seats in Parliament, which is first filled by its candidates who win electorate seats, and then the remainder made up by the eligible candidates from the party's ranked list. Therefore, it permitted candidates from minority groups who would have otherwise struggled to gain a majority of electorate votes under FPP to enter Parliament through a party list.

This possibility was realised immediately: the National Party recruited former Chinese Canterbury regional councillor Pansy Wong and placed her at 26 on their list ahead of the 1996 general election. National subsequently received 34 per cent of the party vote - or 44 
of the 120 seats - and with 12 of the candidates ranked before her winning their respective electorate seats, Wong safely entered Parliament as the first Asian MP.

Since then, the number of members of Parliament who identify themselves as Asian has grown. To date, the New Zealand Parliament has seen the entry of eight members of Parliament of Asian ethnicity, all via their respective party lists. Five of the eight are presently sitting members and they make up four per cent of all members in the House (Ministry of Social Development, 2009).

This outcome conveys the significance of political structures - in this case, electoral systems, and is in line with other research, including one which studied the representation of women in 31 democracies around the world: "[...] Electoral system exert powerful influences on [women's] representation... In turn [it] increases legislatures' responsiveness to women's policy concerns and enhance perceptions of legitimacy" (Schwindt-Bayer \& Mishler, 2005, p. 407).

At the 2011 general election, a non-binding referendum was held to determine whether the New Zealand voting public wished to retain the MMP system, or if not, which alternative voting system they would prefer in its place between FPP, preferential voting (PV), single transferable vote (STV) and supplementary member (SM). Tables 1 and 2 show the results of this referendum, which led to MMP being retained:

Table 1: Results for the 2011 Referendum on the Voting System on 10 December 2011 (Part A)

\begin{tabular}{|l|c|c|c|}
\hline \multicolumn{3}{|c|}{ Part A - Should New Zealand keep the Mixed Member Proportional (MMP) voting system? } \\
& Number of votes & $\begin{array}{c}\text { Percentage of valid } \\
\text { votes }\end{array}$ & $\begin{array}{c}\text { Percentage of total } \\
\text { votes }\end{array}$ \\
\hline KEEP & $1,267,955$ & $57.77 \%$ & $56.17 \%$ \\
\hline CHANGE & 926,819 & $42.23 \%$ & $41.06 \%$ \\
\hline Total valid votes & $2,194,774$ & $100.00 \%$ & $97.23 \%$ \\
\hline Informal votes & 62,469 & & $2.77 \%$ \\
\hline Total votes & $2,257,243$ & & $100 \%$ \\
\hline
\end{tabular}


Table 2: Results for the 2011 Referendum on the Voting System on 10 December 2011 (Part B)

\begin{tabular}{|c|c|c|c|}
\hline \multicolumn{4}{|c|}{$\begin{array}{l}\text { Part B - If New Zealand were to change to another voting system, which voting system would you } \\
\text { choose? }\end{array}$} \\
\hline & Number of votes & $\begin{array}{l}\begin{array}{l}\text { Percentage of valid } \\
\text { votes }\end{array}\end{array}$ & $\begin{array}{l}\text { Percentage of total } \\
\text { votes }\end{array}$ \\
\hline $\begin{array}{l}\text { First-Past-the-Post } \\
\text { (FPP) }\end{array}$ & 704,117 & $46.66 \%$ & $31.19 \%$ \\
\hline $\begin{array}{l}\text { Preferential Voting } \\
\text { (PV) }\end{array}$ & 188,164 & $12.47 \%$ & $8.34 \%$ \\
\hline $\begin{array}{l}\text { Single Transferable } \\
\text { Vote (STV) }\end{array}$ & 252,503 & $16.73 \%$ & $11.19 \%$ \\
\hline $\begin{array}{l}\text { Supplementary } \\
\text { Member (SM) }\end{array}$ & 364,373 & $24.14 \%$ & $16.14 \%$ \\
\hline Total Valid Votes & $1,509,157$ & $100.00 \%$ & $66.86 \%$ \\
\hline Informal votes & 748,086 & & $33.14 \%$ \\
\hline Total votes & $2,257,243$ & & $100.00 \%$ \\
\hline
\end{tabular}




\section{Chapter IV: Asian-New Zealanders}

The first Asian arrivals in New Zealand date back to the latter half of the nineteenth century. Most of the migrants at the time were from China, which was then "beset by overpopulation, land shortages, famine, drought, banditry, and peasant revolts." The first known Asian settler is believed to be Appo Hocton, or Wong Ah Poo Hoc Ting, who arrived in Nelson in 1842:

\footnotetext{
"Appo Hocton arrived in Nelson in 1842, within months of its settlement. As a nine-yearold boy, Wong Ah Poo Hoc Ting left his village in Guangdong province, South China, to become a cabin boy on English sailing ships. In his early 20s, he was a steward on the immigrant ship, the Thomas Harrison, bound for New Zealand. After jumping ship in Nelson, he was employed by the vessel's former surgeon, Thomas Renwick, as a housekeeper, saving enough to buy a bullock team and establish a carting business" (France, 2014).
}

Migrants from China came to New Zealand in pursuit of gold in the Otago fields. On top of dire conditions at home, the discovery of gold in places like California in the United States and Canada as well as New Zealand prompted an exodus, although most arrived with intentions of returning home after reaping their mineral fortunes. This was one of the reasons they were recruited by the Dunedin Chamber of Commerce. They were also seen favourably because they were "thought to be hardworking, inoffensive, and willing to rework abandoned claims" (Ip, 2012a).

The first arrival of Chinese gold miners in 1866 was comprised of 12 men; by 1869, this number had grown to over 2,000. However, it did not take long for anti-Chinese sentiments to flare up, with calls for restrictions on the number of Chinese migrants. In 1881, the Chinese Immigrants Act posed a poll tax of $£ 10$; by 1896, this had increased to $£ 100$. While this poll tax is probably the most well-known of the anti-Chinese measures that were introduced around this time, they weren't the only ones (Ip, 2012b):

1. After 1907 all arrivals were required to sit an English reading test;

2. In 1908 naturalisation of Chinese was stopped and did not resume until 1952;

3. From 1908 Chinese who wished to leave the country temporarily needed re-entry permits, which were thumb printed; 
4. From 1920 entry to New Zealand was by permit only, which severely restricted the numbers of Chinese immigrants;

5. Permanent residency was denied from 1926;

6. Chinese people were deprived of the old age pension until 1936.

Some of the Chinese population remained in New Zealand even after the goldfields were depleted. They moved into other areas of the country, opening fruit shops and grocery stores. According to New Zealand Asian studies scholar Manying Ip, it wasn't until the late 1930s that Chinese populations laid proper roots. This was attributed to a liberalisation of residence requirements:

\footnotetext{
"After 1939 wives and children of Chinese men in New Zealand were allowed temporary entry as refugees from war-torn China. Rather than indicating a fundamental change of immigration policy, the more liberal residence requirements that were introduced in 1947 were prompted by humanitarian concern about adverse conditions in China. Those granted permanent residence included wives and children who had arrived as refugees after 1939, New Zealand-born babies of the wives, and Chinese temporary residents and students who had been in New Zealand for over five years" (Ip, 2012c).
}

The Indian population in New Zealand has its roots that go back to around the same time as the first Chinese arrivals. Most were temporary labourers who came from the regions of Punjab and Gujarat, and like the Chinese, few had intentions of settling in New Zealand permanently; most wanted to earn money and return home (Taher, 1970, p. 4).

\footnotetext{
"Overpopulation, underemployment, and the decline of village industries led many Indians to seek advancement in other countries. The rising standard of living, combined with crippling family wedding expenses, also made it vital to earn more money. Gujaratis and Punjabis had always had close contact with Westerners through British-run industries in India, and were aware of opportunities overseas. Some who were seafarers or employees of British civil servants heard about New Zealand's employment possibilities" (Swarbrick, 2012b).
}

Like the Chinese, however, the early Indian settler population encountered racism and prejudice. In 1899, the Immigration Restrict Act was passed. Prior to this, Indians had been able to enter New Zealand freely as part of the British empire; the Act meant that anyone not of "British birth and parentage" was required to fill out their immigration 
application in a European language. Despite such efforts, the Indian population in New Zealand still grew, as it remained relatively easy for a resident Indian-New Zealanders to bring in their relatives, or for others to enter New Zealand under temporary permits then apply for permanent residency later (Swarbrick, 2012a).

Gradually but eventually, these early Asian populations grew in number and became a permanent part of New Zealand. Ip elaborated: "Greater security and standing in the community enabled families to prosper. By the 1960s many offspring had become successful professionals." Accordingly, earlier prejudice subsided, as it was also around this time "[the] overt racism and discrimination on the part of the host community began to recede," - that Asian-New Zealanders, who were predominantly of Chinese and Indian ethnicity at the time, expanded their participation in New Zealand society and increasingly adopted the common "way of life." They pursued higher education in greater numbers and sought employment in the public service as well as in private businesses and industries, instead of succeeding the traditional family profession which, until then, had been largely limited to "dairy-owners, green grocers [and] market gardeners" (Vasil \& Yoon, 1996, p. $40)$.

The significant growth in the country's Asian population in more recent decades is in part due to the Immigration Policy Review of 1986. It marked a shift away from the earlier emphasis that New Zealand's immigration policy had on nationality and ethnic origin in determining who was allowed into the country. It led to the introduction of the Immigration Act 1991, which involved a points system: “Applicants were awarded points for employability, age, educational qualifications and settlement funds. A modest level of English was required. Under the points system, any applicant achieving a minimum number of points was automatically eligible for admission" (Beaglehole, 2012). Consequently, more migrants from non-traditional source countries - namely Asians from countries like Hong Kong, the Taiwan and the Republic of Korea - were able to meet the criteria to emigrate to New Zealand, and their numbers accordingly grew.

Despite their lengthy history and their flourishing public participation, Asian-New Zealanders have only recently seen the election of "one of their own" to the representative political body of the national legislature. In the 1970s, Ron Wai Shing - who was Chinese - had stood twice as the Labour Party's candidate for the electorate of Franklin, but he was 
unsuccessful both times with the long-time right-leaning constituency favouring the National Party's Bill Birch (S. Young, 1996). However, in 1996 - some 20-odd years later and accompanying the introduction of a new electoral system - Pansy Wong became New Zealand's first Asian member of Parliament. 


\section{Chapter V: New Zealand's Asian Members of Parliament}

To date, the New Zealand House of Representative has seen the election of eight members of Asian ethnicity. At the time of writing, five of the eight are presently sitting members. They vary in origin, from Chinese, to Indian, to Pakistani and Korean, and they draw from political parties across the spectrum. This chapter comprises of brief biographies of each of the current and former members of Parliament that covers their professional and education background, and some of their experiences once in Parliament:

\subsection{Biographies}

\section{Pansy Wong}

Wong became New Zealand's first Asian member of Parliament when she was elected in the 1996 general election, after being placed at 26 on the National Party list (Chief Electoral Office, 1996). She was born in China and drew up in Hong Kong before immigrating to New Zealand with her family in the mid-1970s. Wong gained a Master of Commerce at the University of Canterbury and worked as an accountant, eventually becoming chief financial controller at Smiths City, a Christchurch retail chain.

In 1989, she was approached to enter local body politics and joined the Canterbury Regional Council. Ahead of the implementation of the new Mixed Member Proportional electoral system in 1996, Philip Burdon - the National Party member of Parliament for the South Island electorate of Fendalton at the time - asked Wong to stand as a candidate for his party (Herald staff, 2008b). She was re-elected in subsequent general elections through the party list, having been ranked at number 11 in 1999 (Chief Electoral Office, 1999), 10 in 2002 (Chief Electoral Office, 2002), and 20 in both 2005 and 2008 (Chief Electoral Office, 2005, 2008).

Wong has been involved in a number of community organisations and committees, including the New Zealand Tourism Board, the Asia New Zealand Foundation and the National Council of Women of New Zealand (Herald staff, 2008b; Parliamentary Library, 2011b). 
In 2008, she successfully ran as a candidate for the newly-created electorate of Botany in Auckland and was successful. Subsequently, she was named Minister for Ethnic Affairs and Women's Affairs, and Associate Minister for the Accident Compensation Corporation (ACC), and Energy and Resources, making her the first Asian Cabinet Minister (Parliamentary Library, 2012a).

Wong's parliamentary career came to an end following allegations of misuse of taxpayer funds. In late 2010, it was revealed that Wong had used her parliamentary travel entitlement to pay for costs of her husband's overseas travel during which he had carried out private business. This breached the rules around the entitlement, which prohibited any private business activities on trips funded by it. Wong resigned from Cabinet in November 2010 and some weeks later resigned as a member of Parliament, saying the situation had become an "unnecessary distraction" for the Government (Cheng, 2010; Watkins, Kay, \& Small, 2010). Since her resignation, Wong has been absent from public life.

\section{Ashraf Choudhary}

Prior to entering Parliament, Choudhary was an environmental scientist. Originally from Pakistan, he completed a Master's degree from Newcastle University in the United Kingdom and a doctorate at Massey University in Palmerston North, where he subsequently had a thirty-year long career in teaching and research (Pakistan Institute of Legislative Development and Transparency, 2004). Specialising in agricultural engineering, he became an associate professor, a position he held up to his election via the Labour Party list in the 2002 election. Choudhary was ranked at 40 on the list in 2002, 25 in 2005, and 31 in 2008 (New Zealand Labour Party, 2005, 2008). He served as the Labour Party spokesperson for Food Safety and Agricultural Science, and Associate Spokesperson for Ethnic Affairs, as well as serving as a member of the Primary Production, Local Government and Environment, and Education and Science Select Committees (Parliamentary Library, 2011a). He was previously the president of the Federation of Ethnic Councils, and the founding member and President of the Federation of Islamic Associations of New Zealand. After three terms in Parliament, Choudhary announced he would not be seeking re-election, and retired at the 2011 election (Stuff staff, 2011a). Since then, Choudhary has been active in Auckland's Pakistani and Indian communities, in 
particular encouraging youth involvement in politics and blood donation drives (Choudhary, 2012; Raman, 2012).

\section{Kenneth Wang}

When the ACT Party gained nine seats in Parliament following the 2002 election, Wang had been ranked tenth on the party list. However, following the expulsion of Donna Awatere-Huata, he entered Parliament in 2004 as the third member of Parliament of Asian ethnicity in New Zealand. Wang emigrated to New Zealand from China in 1986 and after obtaining a Master of Fine Arts from the University of Auckland, he spent nearly two decades working in advertising and marketing, and eventually established his own advertising and media agency (Wang, 2008b).

Wang founded the ACT Party's Asian chapter, as well as the Chinese Conservation Education Trust, and served as the president and chairman of a number of community organisations. While in Parliament, Wang was the party spokesperson for Commerce and Small Business, and Associate Spokesperson for Education. He was also on the Commerce Select Committee (ACT Party, 2005; Commerce Committee, 2005; Wang, 2008c).

Ahead of the 2005 election, Wang rose from his original ranking to seventh on the party list (ACT Party, 2005), but this did not ensure his return as a MP, with the party attracting only enough votes to secure two seats in Parliament (Parliamentary Library, 2005). In the 2008 election, Wang chose not to stand on the party list, and instead sought entry into Parliament by contesting the electorate seat of Botany (Wang, 2008a). He was unsuccessful, losing to National's Pansy Wong. Wong gained 56.2 per cent of the votes, compared to Wang's 15.3 (Parliamentary Library, 2012a).

While no longer a member of Parliament, Wang has continued his involvement with the ACT Party, most recently being named as the party's deputy leader and being placed at number two of its list ahead of the 2014 general election (Cheng, 2014; Dastgheib, 2014).

\section{Kanwaljit Singh Bakshi}

Bakshi migrated from India with his family in 2001 after working in his family's freight business as a marketing manager. Shortly after arriving in New Zealand, he undertook a 
number of business ventures including in the property, wholesale and fashion industries, and became involved with the National Party (Bakshi, 2010). He was the deputy chairman of the India Trade Group and an executive member of the Auckland Indian Association, as well as serving as vice-chairman of the Hindu Heritage Centre's Management Committee and as the secretary of the Auckland Sikh Society. He also founded the Sikh Naujawan Sabha organisation (New Zealand National Party, 2013a). Bakshi joined Parliament after being placed 38 on the party list in the 2008 election. He stood as a candidate in the electorate of Manukau East, but lost to the Labour Party candidate and incumbent Ross Robertson by a margin of nearly 50 per cent (Parliamentary Library, 2009). At the 2011 election, Bakshi was placed at 35 on the party list (New Zealand National Party, 2011), and again contested Manukau East but lost to Robertson who increased his margin by a further 10 per cent (Parliamentary Library, 2012b). He has previously served on the Government Administration, and Justice and Electoral Select Committees. He is currently a member of the Government Administration and Commerce Select Committees (New Zealand National Party, 2013a; Parliamentary Library, 2010a).

\section{Raymond Huo}

Trained as a lawyer in China, after which he worked in association with the United Nations and the World Bank, Huo came to New Zealand in 1994 and became an Asian affairs reporter for the New Zealand Herald. Later practicing as a barrister and solicitor in Auckland, he has also published a number of books as both an author and translator, and acted as an on-call bilingual lawyer for the New Zealand Customs Service. Huo became a MP after being ranked 21 on the Labour Party list ahead of the 2008 election (A. Young \& Oliver, 2008). At the 2011, he was ranked again at 21 (Stuff staff, 2011b).

$\mathrm{He}$ is the current chairman of the Kiwi Asian Development Forum and a trustee on the board of the Asia New Zealand Foundation (Asia New Zealand Foundation, n.d.; Kakubayashi \& Ginestet, 2009). In Parliament, Huo is currently the Labour Party's spokesperson for Statistics, and Associate Spokesperson for Ethnic Affairs, Education (Export Education), Justice, and Building and Construction (New Zealand Labour Party, 2014). He sits on the Justice and Electoral Select Committee (Parliamentary Library, 2014c). 


\section{Melissa Lee}

Born in South Korea, Lee's family moved to Malaysia and later, Australia before settling in New Zealand in 1988 (Zwetsloot, 2009). With a Master's degree in communication studies, she worked as a reporter for various publications including the Sunday News, the New Zealand Herald and the Listener. Subsequently, she became a presenter and producer for state broadcaster TVNZ's Asia Down Under (New Zealand National Party, 2013b) - positions she held for fifteen years up to her election into Parliament. Lee has held a number of community positions, including vice-president of the Korean Society and the Korean Women's Association, and board member of the Asia-Pacific Producers' Network. She has also been a member of various associations in the media and production fields, as well as acting as an advisor to the National Unification Council of Korea and as an Asian advisor to the Auckland Police. Placed 37 on the National Party list, Lee entered Parliament following the 2008 election and served as a member of the Commerce, and Law and Order Select Committees (Kirk, 2008; Parliamentary Library, 2010b).

At the 2011 general election, Lee was ranked at 34 (New Zealand National Party, 2011) and in the subsequent term was appointed to a newly-created role of Parliamentary Private Secretary for Ethnic Affairs, as well as chair of the Social Services Select Committee (New Zealand Government, 2011).

\section{Rajen Prasad}

Born in Fiji to Fijian-Indian parents, Prasad first came to New Zealand on a working holiday as an 18-year-old in the 1960s. He later obtained a doctorate from Massey University and went onto pursue a career in practical and academic social work. Appointed as an associate professor and Director of the Department of Social Policy and Social Work at Massey, he worked at the United Nations' regional headquarters in Thailand (Grigg, 1998). Prasad was the country's Race Relations Conciliator from 1996 to 2001, and served as a member of the Residence Review Board in 2003. He was the founding Chief Commissioner of the Families Commissioner from 2004 until the 2008 election, when he became a MP for the Labour Party (Napier, 2009; Parliamentary Library, 2010c). Prasad was given a remarkably high ranking on the list which, at 12, was higher than several senior members and safely guaranteed his election (Herald staff, 2008a). At the 2011 election, he was placed at number 20 (New Zealand Labour Party, 2011). 
Currently, Prasad is a member of the Social Services Select Committee and the Labour Party's associate spokesperson for Ethnic Affairs and Social Development (Parliamentary Library, 2014b). Ahead of the 2014 general election, Prasad announced that he would be retiring, saying that after six years, he had made his "parliamentary contribution" (Vance, 2014).

\section{Jian Yang}

Dr Jian Yang entered Parliament at the 2011 general election as a member of Parliament for the National Party, having been ranked at 36 on the party list (Chief Electoral Office, 2011). Prior to politics, Yang had a career as an academic, most recently a Senior Lecturer of International Relations at the University of Auckland, and the director of the China Studies Centre for the New Zealand Asia Institute (Chapman, 2011). He gained a Master's degree and a doctorate from the Australian National University, and has had involvement with the New Zealand Institute of International Affairs and the New Zealand Council for Security Cooperation in the Asia-Pacific, as well as acting as a commentator on international affairs and Chinese politics. He is a current member of the Commerce Select Committee (Parliamentary Library, 2014a). 


\section{Chapter VI: Themes from Interview Data}

\subsection{Research Methodology}

The following section of this thesis will draw from information gathered through a series of in-person interviews. These interviews were conducted over a period of approximately 12 months, between November 2012 and November 2013, totalling 12 hours of recording time.

The participants -11 in total - can be categorised into one of two groups:

1. Current or former members of Parliament (six);

2. Current or former political party officials (five).

Of those interviewed, only a proportion expressed a preference for anonymity. However, for the purposes of consistency, the identities of all subjects have been redacted. This approach circumvents the inevitable risk that is created by the relatively small number of individuals involved; the limited pool of possible participants means that the identification of some, but not all of those interviewed could reasonably lead one to deduce the identity of others through a process of elimination.

Nonetheless, the relevance of context is recognised in the use of this primary data and as such, the position (current or former member, or current or former party official) and the party affiliation of individuals will be disclosed when directly quoting or interpreting comments and remarks derived from the interviews.

In identifying aspects of minority representation to consider, a group of researchers have identified some contributing factors:

1. "Channels of access" for minority candidates (candidate nomination procedures, electoral rules, party systems and campaign financing)

2. "Policy focus and outcomes of minority representation"

3. "Nature of connections between minority representatives and minority communities" (Bird, Saalfeld, \& Wüst, 2011, p. 2). 
The responses provided in the course of the interviews have been grouped in distinctive themes that address these factors.

\section{Entry into Parliament}

There was variation in the members' involvement with the party, ranging from close to none prior to their entry into Parliament, to decades as a member or as a volunteer. Most, however, harboured some interest in politics prior to becoming politicians:

\footnotetext{
"My family was actively involved in politics before we migrated to New Zealand. So I always had an intention to be politically active wherever I lived." - Current member

"I've been interested in politics since I was seven." - Current member
}

The members were asked what traits they believed qualified them to act as a representative. They ranged from community involvement, to having a public profile, to personal qualities:

"I like to think that I'm not shy, and you know, I'm fairly articulate." - Current member

"Through my work, I was known. But I also represented the views of people because I knew what the difficulties were in terms of migrants settling in New Zealand." - Former member

“Apart from [some things], I speak English. If I didn’t speak English, I'd probably have had a difficult time getting selected." - Current member

"It's a combination of lots of things. I think for someone coming from another culture, I think it's very important for you to get yourself established in the first place. Which means you need to understand the structure, the society, the people. For instance, how New Zealand has been progressing from the bicultural to multicultural society. So that matters." - Current member

Accounts differed on how they came to stand as candidates:

"I was shoulder-tapped by [my party]. Years ago. The party president [at the time] to me... and [a former member of Parliament]. I wasn't so sure, I'm thinking, 'Oh, gosh.' I turned 
them down that first time [because of] family commitments. [But] then they asked again... at the next election, and that time, obviously, I said, 'Yes."' - Current member

"I've kind of been around the party, helping and volunteering. Not really heavily involved, but just on the periphery. Then I was approached." - Former member

"I had a long-standing involvement with the party. Ever since we arrived here [in New Zealand.] I've been a member of the party, I've volunteered." - Former member

"They [the party] approached me, but I wasn't interested. You know, I had a lot to think about. Obviously my views matched up [with that of the party]... But still, I had never gone out and made it known so they knew to ask me... that I'd be interested." - Current member

"There was never a promise that they were going to get me there. They wanted me to stand but I had to go do a big interview and convince people." - Current member

\section{Most interview participants acknowledged the significance of their ethnicity:}

"I think my ethnicity is important to my personal identity. I consider myself Kiwi-Asian." - Former member

"If I said that it wasn't significant then it would be the wrong answer but if I said it was the most significant thing it would also be the wrong answer. I think my ethnicity is definitely one of the reasons why I was chosen - you know, you could say there are other people who are much more qualified than I am." - Current member

"I think one of the things I have that's to my advantage is that I'm representing the ethnic community." - Former member

"I guess one of the reasons why the party chose me to be on the list was because I was of an ethnicity that wasn't represented in Parliament." - Former member

A few, however, were less certain, or dismissive of the extent of the influence of their ethnicity:

"I know I got into Parliament because I had a long involvement with the community and the party... A long history of representing the views and aspirations of the ethnic 
community. And of course my background and connections. I think I am here like any other [member of Parliament], not just because I'm Asian." - Current member

"It's up to the party to answer why I was selected, not me." - Current member

"I don't know [what role my ethnicity had]. That, you probably need to ask the party. I guess, they probably thought I could contribute something, you know. I don't think they choose people who can't contribute. I mean, I'm active in my select committee, I'm active in my parliamentary role and I'm debating in the chamber, I'm active in the community, you know. They picked me before they knew all that, but I suppose they figured that's what I'd do." - Former member

“I think I would still have made it into Parliament... if I wasn't a minority. I mean, with my experience. I was also fairly well-known.” - Current member

One participant revealed that his party had openly sought him out on the basis of his ethnicity:

"Of course it was [something they admitted]. They wanted this diversity of New Zealand to be represented in the Parliament... It was essential for [the Party] since our Asian population had been growing very fast and [at the time] we had no representation in Parliament." - Former member

\section{Comments from other supported this:}

"You take part in political meetings and the issue is discussed. [The issue] of how to represent the Asian community. People want to know if you're interested and you know, when my time came, I said yes." - Former member

"First, a senior member of the party asked me to stand. Then someone even more senior came to me the year after. They wanted more diversity in the party." - Former member

Some were quick to add that their entry into Parliament was not without competition:

“Of course there was competition. Our party is democratic, they've got processes in place and they want diversity but not just diversity of ethnicities. So just because I was Asian it wasn't a guaranteed thing. There's gender representation, other ethnic representation... All those things." - Current member 
"It was a democratic process. The delegates vote for the list ranking and I went through that, like the other candidates." - Current member

"I didn't know where I would be ranked [on the party list] before I was ranked. You don't know. It wasn't guaranteed. I mean, you kind of get the idea that you're safe, people tell you, but I mean... The people I was talking to weren't the ones that decided at the end of the day." - Current member

\section{Motivations for entering Parliament differed:}

"I mean, this was the major thing I had always thought about. I thought this was a way to crystallise the dreams of our people. You know, come to Parliament and that way [I could] impact the policies which impact our people." - Former member

"Like I said, I wanted to be a politician for a long time. I thought I would be good at it." Current member

"One, I had a passion for politics. Two, I had a dream of becoming a politician ever since I was a child. Thirdly, it's my opportunity in my mid-life, I guess.” - Current member

"One of the things I really want to do is give back, make New Zealand better, and make policies that make New Zealand wealthier, safer... And I think you know, being given the opportunity to speak in Parliament as one of 120 people is an absolute privilege." - Current member

"I wanted to make a difference." - Former member

\section{The role of a member of Parliament}

One specific question that was asked of the current and former members was what they perceived their primary role in Parliament to be. There was surprising unanimity in the initial responses to this question:

\footnotetext{
"There are a lot of primaries... One is that we actually make law." - Former member

"Well - essentially, to all of the [members], [it's] to make laws. We are legislators." Current member
}

"The primary one is to make good laws." - Former member 
"We come to Parliament... a place where laws for the country are made." - Current member

Others elaborated on their answer to this question:

"We are here to promote the interest of our people and help our people and promote policies. [I'm] keen and have been very keen to promote the policies affecting ethnic communities in New Zealand [particularly].” - Current member

Some rejected the suggestion their ethnicity posed a limitation as a representative:

"I'm not just representing the ethnic community. I'm representing all New Zealanders." Current member

“There's more to be as a member of Parliament that just being the 'Asian' one. I work. I don't just sit there and think I'm doing by job." - Current member

One respondent believed his role as a representative differed as a result of his ethnic background, and indicated a cultural gulf between New Zealand's migrant and general populations:

"I have had a very different role... You know, apart from being a legislator here I have the role of [an] educator for our community because our [ethnic] communities come from very different backgrounds and they need to understand the New Zealand way of life, our democracy, our belief in justice and fairness... All the areas which many from migrant communities are not fully aware." - Former member

This suggested role of an "educator," however, was echoed by others:

"Some of the people from my ethnic community... are often new migrants coming through the settlement period. They need help in terms of understanding how to access government services, you know?" - Former member

"I think the responsibility of the member of Parliament is to represent his constituents... [and to] bridge the policies of the party by educating, educating the people about those policies so they can take advantage of them." - Current member 
Other respondents did not explicitly state their role as a representative was any different because of their ethnicity, but discussed some of the activities they were able to carry out, that their non-Asian peers in Parliament could not, or portrayed the role as an intermediary between Parliament and their ethnic communities:

"I've been able to take our leaders and our candidates to places they've never been before... Like ethnic churches. Places they’ve not been reached before." - Former member

"Some members of the ethnic community don't speak English, or they don't speak English very well. Me, I speak four languages, and that helps some people feel more comfortable raising concerns in their own language. Otherwise... what would they do?" - Former member

"I understand the [ethnic communities'] culture, where they're coming from. If they're talking sensibly about [an issue] then that's my responsibility, to take it to the relevant authorities. If they're not talking sensibly then [I] pacify them, say, 'No, this is not the way, you have to understand.' I bridge the gap, or try to reduce the gap if there is a genuine issue which is not being taken up." - Current member

"I try to be more aware of issues affecting my ethnic community. I think, [I] sort of look at policy and I think my role is sort of a go-between? You know, to not just bring views of the constituency to Parliament and to my party, but also how the law affects these people, so I'm sort of the conduit." - Current member

"There is nothing like having that experience, it's like, when you talk in Parliament as well, sometimes your own personal experience makes you a better speaker. I think, having been through the migration process, the settlement process, what it's like to be a [ethnic minority] speaking the language, I think I understand better than most what it's like to be [an ethnic minority] in New Zealand." - Former member

"I convey [a] message to my community... because many of the members are from a regime or country whose system is different from the New Zealand system. So they need to be able to understand the system and how the law be connected to here and that's one of the important procedure in order for them to be settled as a happy New Zealander." - Current member

More than one of the current and former member of Parliaments, however, made the point that they still had the same responsibility as their non-Asian peers: 
"Sure, they have electorates. But so do I... Mine is the ethnic community that's spread all over New Zealand." - Current member

"I think my electorate are the ethnic communities." - Current member

"I guess I'm like any other member of Parliament. I'm a representative of a constituency. And my constituency isn't actually bound by regional, geographical boundary, but my constituency is in fact sort of race-based. I guess I am, I represent the view of the minority community that actually currently exists in New Zealand." - Current member

"Am I like, am I different because I'm an ethnic minority? I'm no different. I do the same job but I have that added bonus of being the ethnic." - Former member

Some went on to state the ways they reconcile their roles as a member of an ethnic minority and a member of Parliament:

"I represent the ethnic community, but I also represent the mainstream. Like for example, I have experience in business so sometimes I speak in terms of my background there." Current member

"Obviously I have some responsibility to ethnic communities. But I feel equally responsible for everyone who approaches me. I don't say that if any white person or Pacific Island person came to my office - 'I don't represent you.' I represent everyone." Former member

"I'm representing a certain sector of New Zealand because of my ethnic background. But when we make laws we make them for all New Zealanders." - Current member

"We make law... I [also] represent the views of my constituency, which is [my ethnic community] as well as the electorate [where I stood] last election. So I guess I am a voice for my constituency." - Current member

"You know, you can't just be an ethnic [member of Parliament]. I'm a [member] who just so happens to be of [ethnic origin]. Which might mean I have a better perspective than others on some issues, and I represent some people on certain issues moreso than other people might." - Former member

"It's very important for me to stress that, it's very important for me to say, I'm elected to represent New Zealanders, so not necessarily any particular ethnic group. And secondly, 
having said that, because of ethnic background, and because of language and culture, sort of knowledge, and of course you feel obliged to represent your own community." Current member

Interview participants were asked for their thoughts on how their presence in Parliament might have had wider effects:

"Well, it's affected the campaign I've run in elections. And of course, we campaigned to gain the votes of people from my ethnic group." - Former member

"As a candidate I went out to my community... my ethnic community, to seek their votes and to hear their voices." - Former member

"I think before there were Asian [members of Parliament], there wasn't any enthusiasm to vote because our people couldn't click with the parties. There was no connection and they couldn't relate to the politicians." - Former member

"[Members of thaw ethnic community] are becoming more and more politically aware." Current member

“After the last election, I had people thanking me, that if it wasn't for me that they wouldn't have experienced what it's like to be actually involved in an election and campaigning and door-knocking, walking with me door-knocking - they've never known anybody to do that before. And they've actually experienced that whole thing with me, so they felt really empowered by that." - Current member

Current and former members were asked in particular about any efforts by their parties to target their ethnic communities:

"Yes, yes... They take our input and our suggestions [on] what should be done to facilitate our communities. Like pamphlets in different languages. People should understand the policies of the party and language is one of the barriers and... if you present something in their own language they, Asian people, they feel more comfortable and it is easier for them to understand." - Former member

"The ethnic members of our caucus meet pretty regularly. Like, we meet up and talk about what issues could be important." - Current member 
"If you're talking about trying to target ethnic votes, of course [my ethnicity] is definitely an advantage because I represent something that most aspiring migrants actually want, that an ethnic minority can become a member of Parliament. It encourages them to get involved." - Current member

One member, on the other hand, criticised their party's campaigning efforts:

\begin{abstract}
"One of the things the party did really poorly was the ethnic campaign... I felt that it was not in the forefront of their campaign strategy. I think they know it but maybe it's my fault? But I'm not a decision-maker so I can't exactly say, let's do 10,000 [ethnic] pamphlets, I can't say that, I'm not the one who's actually responsible. But I think the senior members of the campaign team should have actually said, 'Okay, we've got ethnic media, ethnic communities, ethnic [members of Parliament], where are we going to send these people and how we're going to campaign?' I don't think there was [a strategy], I think we were slightly doing our own thing. And then in the end there were some pamphlets and media advertising and all that sort of thing but I don't think it was at the forefront but you know, percentage is actually quite small." - Current member
\end{abstract}

Other participants claimed they did not target their ethnic communities:

"A vote is a vote. I approached everyone, hand-delivered flyers, door-knocked... Not just [door-knocking] on ethnic doors but I went to each and every door." - Former member

\title{
Life in Parliament
}

When asked to describe what they did when in Parliament, both current and past members of Parliament portrayed an existence not too dissimilar of what might be expected of any other member of the legislature:

"I sit on select committees, look at legislation." - Current member

"I try to bring the issues that are important to my constituency, the people I talk to... to

Parliament to ensure they're heard and attention is paid to them." - Current member

Interview participants were asked what issues were most important to them as members of Parliament: 
"The key issues for me have been, you know, to help our ethnic communities... To bring their voices to Parliament and ensuring these people get as good representation as other people - ensuring their voices are heard. They've been the issues for me." - Former member

"Business. I know that businesses what minimal bureaucracy and less paperwork. We should create an atmosphere that helps businesses." - Current member

"Welfare reform. Law and order." - Former member

Some participants believed that once elected, they were given the opportunity to prove themselves:

"Ethnicity might have been a factor in me getting in [to Parliament]. But I've worked hard since I've gotten in." - Current member

"I think people can look at things I have done... My accomplishments... And see that I've done a good job. At the start they might have thought I was just there because of my ethnicity. But since I've come to Parliament, you know, I've spoken out on behalf of my constituents, I've stood up for things that matter." - Former member

\section{Perceptions}

A common frustration that some interview participants expressed was being perceived as "just the Asian member of Parliament."

\footnotetext{
"There's more to me than my ethnicity. When I come to Parliament, I contribute. In terms of law, in terms of talking about the issues. What does my ethnicity have to do with that? It's not the only thing that matters." - Current member

"Sometimes you come across the view people think you're just in Parliament because my skin is a certain colour. I guess it bothered me, because it kind of takes the attention away from the work I do. Like on select committees, out in the community." - Former member
}

Others, however, were more dismissive.

"Well, other people might see it that way, non-Asian people. But I don't think it's a problem." - Current member 
"Look, [the] time will come, they will see that we contribute more than anybody else. We are working hard for that." - Former member

"I might get boxed in as the [ethnic member of Parliament] but I don't have a problem with that." - Current member

"So what if people think what they want? It doesn't minimise the work I do. Just because they don't know I do them, I don't feel that I should go and prove that I do the work. I do the same job as any other member. Sometimes I think I do more as a list member. You know, not only are we doing our constituency stuff but we also travel outside of our own areas and actually deal with ethnic communities. And sometimes there are frustrations because you sort of think, 'Oh, yeah, you're an Asian MP,' - well, I am. But I don't see it as frustration or negativity - we have a growing population who are of ethnic origin." Current member

Some even regarded the perception as a positive point, and that early perceptions may have changed over time:

\footnotetext{
"Well, when I came in, in the early days, you felt like you were the only one. Like a token. But as I've said, I'm very proud of it, of what I've done. I have come up from the bottom." - Former member
}

"I think maybe when I first got in there might have been... I don't know, maybe the ethnic [members of Parliament] probably felt that we were actually ethnic? But once you... But I think that's because we're just new, and we were trying to find our feet, really. I think once we actually sort of got working into the select committees, and House rosters and debating in the House, we're like anybody else, we're no different to anybody else." - Current member

\section{On the electoral system}

An obvious feature that all the current and former Asian members have in common is their entry into Parliament. Beginning with Pansy Wong, each of the eight members gained election through their party list. While Wong openly admitted that without MMP, she would not have been elected to Parliament, the rest were somewhat divided in their views.

"[MMP] has been helpful for me, I acknowledge that... but I think I bring other strengths to the table [as a member of Parliament]." - Current member 
“Would I have been elected without MMP? I don’t know... Maybe.” - Former member

"Well, the introduction of MMP gave us the opportunity for all of New Zealand, the different sectors of society... to get into Parliament. The old FPP system was almost impossible for our people, for the ethnic community to get into Parliament." - Former member

"Before MMP, I thought it would never happen. The way the structure was." - Former member

"I think [MMP] is probably better than first-past-the-post. Though mind you, though sometimes I think first-past-the-post is actually quite a good idea because we would have got a majority government!" - Current member

"I think MMP was a great idea in terms of getting representation, you know, on wider scale." - Former member

Some current and former members indicated the electoral system had been manipulated by their party, rather than by themselves:

"I wanted to stand in an electorate [in one election], but the party and leadership wanted me to just stay on the list." - Former member

"[Without MMP]... would I have, if I wasn't actually tapped on the shoulder by the party to actually run on list, would I have bothered to stand in an electorate? Probably not." Current member

\section{Party perspectives}

Party officials affirmed the different ways that Asian members of Parliament came to stand as candidates:

"Some of them, their names get passed to us. Others you see at party events." - Former party official

"They'll either approach us or we approach people and ask them." - Current party official 
Party officials spoken to acknowledged their parties' desire for diversity in their lists of candidates, but added that this was not the only criterion they valued:

"To be a candidate of our party... it's all those good qualities that people have, so it's integrity, and the combination of integrity and common sense, of achievement." - Current party official

"All of our members, they bring strengths. [It's] more than just their ethnicity." - Former party official

"I mean, it was very specific there we wanted somebody at least one candidate who met the bill because we are a very diverse party. You want members, that caucus that is representative of the country, in geography, in ethnicity, in gender balance and in experience and skills. So we want to have an overall diversity including obviously ethnic diversity." - Current party official

"I mean, how do you judge, how do you actually judge what is, who is a good, a good MP? The obvious - there are no obvious markers I feel for that. You really have to try and get a balance of skills and age, all of those factors in your caucus." - Current party official

\section{Some emphasised measures to circumvent perceptions of tokenism or ineffectiveness:}

“I think it's important when we do have [members of Parliament] of an ethnic minority that they are also they are given broader portfolio responsibilities. I think giving them responsibilities that mean that they are not seen as or they are not allowed to operate as tokenistic representatives is very important. It breaks down the idea people might have when they look on and say, 'Oh, yeah, you've got your Asian - tick that box, got your Māori - tick that box...' That they have a proper and full role to play in the caucus... It breaks out of any sense that it is just about ethnic identity." - Former party official

"I don't know that they are seen as any less effective. I think they're all quite effective very effective in both their own areas and in general areas too. I wouldn't say that they're less effective than other members. The difficulty is that the language is a barrier to us understanding what the coverage is that they're getting, or how that fits in in the general political scheme, whether that's Cook Islands, Samoan, or Mandarin. It's difficult for somebody, difficult in New Zealand because they are few who have a second language or third language." - Current party official 
Officials were asked their views on what Asian candidates brought to their party:

“Apart from the obvious one of properly reflecting modern New Zealand, I think, you know when I look at the Asian candidates we've had, they've typically come from the professions or they've come from a business background. They bring an internationalism to the party and to the caucus that we wouldn't otherwise have." - Former party official

"[Having Asian members] helps us to be more representative and surely relevant to mainstream New Zealand. Either as new immigrant families or as, you know, several generations of being here they really help give a voice to their communities that otherwise would be missing at the national government level." - Former party official

"I don't have any doubts that they're all really contributing to the overall caucus and committed members. They get to know what Parliament is, what contribution they can make, they're in these select committees and in their constituency work, and really are a part of the party, they're bringing forward connections for us that we otherwise wouldn't have or assisting when, in whatever connections there are back in what was originally their home country. They're able to do that as well." - Current party official

Some officials stated that the inclusion of Asian members of their Parliament affected not just their election campaigns, but also their policies:

"Certainly in terms of immigration policy and our accepting that New Zealand is... We are more global, we need to be more internationally connected. I think having ethnic members shows an acceptance that New Zealand's future is part of an Asia-Pacific realm, not just a European, sort of, Northern Hemisphere sort of realm, and that if we're going to do that you know we need to have to harness the strength of the communities we have in New Zealand to build links back into the rest of Asia." - Former party official

When asked for their views on the electoral system in relation to the election of Asian members of Parliament, the officials responded:

"I think MMP has created an opportunity for us to ensure we have Asian members in our caucus. We've had Asian candidates, we've put them in general seats but that doesn't guarantee election. So MMP has given us the opportunity to say, 'Well, we'll use our list seats to ensure we get Asian candidates in there." - Current party official 


\section{Looking forward}

In the course of the interviews, participants were invited to offer their views on their political futures, as well as the political representation of Asian-New Zealanders in general.

"Us Asian [members of Parliament]... We're still in the early stages of making an impact in Parliament and [in] reflecting the aspiration of our people." - Former member

Current members of Parliament remarked on their ambitions, which ranged from winning an electorate, to being appointed a role in the executive:

"I'd like to become an electorate [member of Parliament] eventually. I'll try too... Let's see, you never know." - Current member

"I won't say I'm 100 per cent satisfied with what I've accomplished, what I wanted to do. But still the contribution I have made... gives me some satisfaction. I'm looking forward to the opportunity [of] how I can contribute further." - Current member

"Of course I want to be in Cabinet. I think if you don't, you shouldn't be here." - Current member

Some indicated their satisfaction with the role they had created for themselves:

"I'm not as ambitious in terms of an electorate seat, per se, I mean, I have a constituency of [ethnic] people and in this environment where there's MMP, being a list MP, I do just as much work as any other electorate MP does. I travel up and down the country going to see people." - Current member

"I am, I am very pleased. I'm actually very proud, seriously. The other day, I was just walking to Parliament for Question Time, I think, I can't remember... I was walking to Parliament, can't remember when it was, and I just had a smile. I thought, 'Isn't this amazing, that I have such a privileged life? That isn't it such a joy to be walking across to Parliament as an elected representative,' - you know, we are elected because MMP means list members of Parliaments are also elected - as elected representative, from what we used to do and what we do now, and even if it's, like, our bodies are tired because sometimes you get up so early in the morning and you go until god knows how many hours, the wee hours in the morning, you feel extremely tired, yet you think back and just go, 'This is like, 
privilege. There are only 120 people in the country who do this.' And it's such a wonderment, it's like, oh my god, wow. It is a real high." - Current member

Other members reflected more generally:

"To me, having [ethnic representation] means the future of [ethnic] settlement in New Zealand is actually, sort of, better. We can be more, better mainstream, that we're not just doctors and nurses and accountants, but we actually do have some influence over policy. They can't just ignore us, that we're not just going to be a silent majority." - Current member

"I want to go as far as possible. But I've said, if I'm no longer needed, and if I'm no longer making a difference, I should leave. I don't see myself as a member of Parliament who stays in Parliament for life. This is not a lifestyle for me. I've taken a cut in salary to be here. This is not something I see I'm going to do until I'm 70 years old, and I'm not going to die in office - that's not me. I feel that I'm making a difference and I'm still learning." Current member

Some interview participants regarded their presence as a milestone, and the positive outcomes they expected from it:

"Being a [member of Parliament] is a great privilege. It's an honour and it's not something you have an automatic right to. So I feel very proud." - Current member

"We have ancestors. They came over years ago, faced hardship. It was bread and butter for them, trying to survive but now look at how far our ethnic groups have come. It's thanks to them... in part." - Former member

"People feel my achievement is quite incredible... They mention it. I get a lot of positive comments, and they also sometimes relate to me as a role model." - Former member

"I think I give a lot of positive, sort of, vibe to a lot of young New Zealanders who happen to be of ethnic origin. And for them to sort of look at me and say, 'Well, if [they] can do it, maybe I can."” - Current member

Participants pointed out the increasing diversity of New Zealand: 
"In the early days, it might have been different. We had main ethnic communities like Indian and Chinese. But now, you know, we have Japanese, Arab, Somalian... We have much wider communities than 10 years ago." - Current member

"Us Asians being in Parliament... It's making the House of Representatives a real House of Representatives." - Former member

"The New Zealand fabric is changing and people are accepting more and more." - Former member

"When you have a population that is diverse, you're going to have to have diverse representation. And perhaps when that actually happens, that you know, people might feel more comfortable voting for people who do look different." - Current member

"New Zealand is no longer mono- or bicultural country, we're multiracial, multicultural country. I think it's very important for us to understand each other, and without representatives or representation from any groups, the chances would be getting smaller and smaller in [understanding]. And in the reality would be served by the actual and effective representation from all sorts of different groups. And of course ideally it's good for any, every single representative, ethnic groups to be represented but in reality, it's nearly impossible." - Former member

\section{A number of participants stated there was more to do:}

"Ethnic communities seek long-term relationships with the political parties... They want more than just paying lip service. They want more respect than just photo [opportunities] that are meant to be all that ethnic people should base their vote on. They want recognition." - Former member

"I think people are realising that there's a need for better engagement." - Current member

"I think we are [still] not well represented. I strongly believe we need more representation." - Former member

"I think it's important for the long-term security and safety of this nation that all sectors of society are represented." - Former member

"It's very important for us to get it started, and get it started now so that's reason why in 1996, when we had the first Asian MP, everybody's excited and so that representation 
should be commended and I'm very glad we have more now. But it's not so good because obviously we need more." - Former member

"You can never do enough. It's all a matter of balance. I feel we could have easily more candidates of Asian ethnicity in the future, I'm sure we will. It's all the balance of the electoral cycle of when new [members of Parliament] are going to come in, and we're a democratic, highly representative party so we need to continue to have that look and feel, so we can't afford to ignore large parts of our communities." - Current member

\section{Some mused about the possibilities:}

“I won't say it's going to happen tomorrow. But we've had an Asian governor-general... [so] why not [an Asian] Prime Minister? What's the reason?" - Former member

"I think New Zealand's system is quite a fair system. I hope that in future the acceptance of [different groups of society] will be wider. I'd like to see more women, not just from the ethnic side, but also overall, also, I hope it will be a better place to debate in." - Current member

“As more Asian people settle and history goes and we get older, I would hope that we become integrated and we are becoming a 'one' New Zealand where there's no colour." Former member 


\section{Chapter VII: Discussion}

From the outset, it is acknowledged that there are limitations to relying on primary data gathered through interviews. Even with anonymity, respondents are likely to provide answers that present themselves in the best light, and dismiss or omit information that reflects negatively on them. There are also issues around individuals' memory; some of the material discussed in the interviews relates to events that took place some years ago, and it is entirely expected that recollections of them may not be exact. Further, the responses are inevitably affected by individual perceptions that differ from person to person, which in turn affect the accuracy of their report.

Bearing this in mind, the interviews conducted as part of research for this thesis nonetheless provide valuable insight into New Zealand's Asian members of Parliament and their role. One apparent finding is the divergence of views between the interview participants - this however, is perhaps not so surprising when taking into account the different experiences of each individual. It highlights the fallacy of treating an ethnic group as one monolithic bloc - if the views of a handful of individuals who share a common ethnic background are this diverse, statements that are made about the ethnic groups at large are likely to be generalisations at best.

An examination of the responses provided by the interview participants do allude to contradictions, or at the least some confusion. The language employed in some of the responses saw the Asian member of Parliaments describe the ethnic communities as "our people," or variations of the term, suggesting a perceived or psychological divide between the Asian ethnic groups and the wider population of New Zealand. However, this is merely intended to be a superficial observation, and to some extent it could be attributed to the openly acknowledged fact that most of the members saw their ethnicity as playing some part in their role as a representative.

There are connections that can be drawn from theories of representation and the responses from the interviews. The foremost, arguably, is John Adams' advocacy for a legislature that is a miniature portrait of society at large, and Hanna Fenichel Pitkin's theory of descriptive representation; an aim that in fact underpinned the implementation of MMP as an electoral system in New Zealand - with the Royal Commission that recommended it 
identifying better representation of minority groups as one of its core reasons. The justification for this seems reasonable; the members interviewed themselves indicated readily that in sharing ethnic origins, they accepted being treated as the representative of the corresponding communities.

But the responses also evoke the premises purported by Hanna Fenichel Pitkin's theory of substantive representation. The current and former members of Parliament talked at length about what they do as representatives, the actions the carry out in order to represent, which they appeared to regard with as much significance as their ethnic origin.

It therefore seems fitting to suggest that descriptive representation and substantive representation do not necessarily pose a choice of either or: "Easier communication with one's representative, awareness that one's interests are being represented with sensitivity, and knowledge that certain features of one's identity do not mark one as less able to govern all contribute to making one feel more included in the polity. This feeling of inclusion in turn makes the polity democratically more legitimate in one's eyes" (Mansbridge, 1999, p. 651). In this vein, it could be argued that descriptive representation, in some instances, could lead to substantive representation.

In fact, studies show that descriptive representation leads to relative substantive representation in the form of policy outcomes that benefit the minority population. Looking at Latino representation in the United States, Preuhs (2007) found that legislatures responded to the inclusion of Latino members, with the wider Latino population benefitting from "legislative incorporation... [such as] social welfare policy" (p.277).

It is difficult to comment on how the findings of this thesis relate to symbolic representation, or the legitimacy of Asian members of Parliament as representatives for Asian communities. This could comprise an area of further study - assessing how the members are perceived and regarded by the ethnic communities they themselves believe they represent. It ought to be balanced with findings that suggest while candidates who share the minority identity of the community they purport to represent and important in achieving substantive political representation, that supportive or sympathetic individuals who don't can, in some instances, still effectively represent the minority group members (Haider-Markel, Joslyn R., \& Kniss C, 2000). 
Acknowledging the diversity of experiences, views and interests that New Zealand's Asian member of Parliament represent as one overarching finding of this thesis, a subsequent, but nonetheless salient finding is that in actively seeking out these individuals as candidates, as the interview responses suggest, the country's political parties are perceiving a need to include them. A cynical take on this would be that parties are regarding ethnic candidates as a means to attract votes. Ethnic candidates, however, could manage this in other ways than simply sharing a voter's ethnic background; as interview respondents stated, things like shared language and culture play a part in their ability to educate and communicate with a public previously detached from politics, as well as providing them with an motivation or vested interest in politics that they might not have had before.

The presence of Asian populations also has wider societal impacts. With regard to the inclusion of an ethnic minority in a given body, it has been argued that their presence alone makes it more difficult for racism to persist within it, and aids a cohesive society:

\footnotetext{
"[When members of an ethnic minority gain election]... the resulting combination of group recognition and an acquired voice in policy-making form an important stage in the assimilation of the group into the community at large" (Cornwell, 1980, p.19).
}

While the notion of microcosmic or descriptive representation may have assisted the initial election of Asian members to the New Zealand Parliament to date, it is however, necessary to recognise that this principle has the potential to become a disservice for the country's Asian population, if the implication is that Asians can only be represented by Asians; it misrepresents the diversity within the Asian ethnic group; the few existing studies of Asian voting behaviour invariably emphasise the necessity of understanding the Asian ethnic group not as a one uniform body, but as a population consisting of diverse origins and backgrounds (Lien, 2004; Park, 2006; Tam, 1995).

As earlier stated, it is difficult to determine the exact influence of candidates' ethnicities on voter behaviour in New Zealand given the lack of research in this field, but studies from overseas may provide some useful information. When Barack Obama launched his campaign for the White House ahead of the 2008 presidential elections in the United States, the possibility of an African-American assuming the nation's highest office for the first time prompted significant interest and coverage of his ethnicity. Despite Obama's 
own denials that it would be the determining factor of his candidacy, it nonetheless attracted considerable pre-election speculation and analysis (Wiessler, 2008). At one stage, his campaign team was accused of "playing the race card" by his Republican rival John McCain (MacAskill, 2008). Obama's subsequent election was widely regarded as a triumph for race relations in the United States, with one poll reporting that over two-thirds of Americans viewed it as among the two or three most important advances for blacks in the past century (Gallup Organization, 2008).

However, one academic, Derald Wing Sue, expressed dissent, suggesting that the event was instead represented a rare constellation of events that most likely "overrode rather than cancelled out" racial biases. Contributing factors included Obama's talent and charisma, the precedent of major national crises and an unpopular Republic president, as well as the suggestion that "some white people voted for Obama because he represents their unconscious view that he is an exception to most black Americans" (as cited in DeAngelis, 2009).

Studies of candidate ethnicity and voter behaviour in the United States indicate a complex status quo. Some findings suggest that voters will misrepresent their genuine preference for aversion for minority candidates to avoid appearing "racist" (Colleau, 1990; Moskowitz, 1994; Terkildsen, 1993), while others suggest that race bears no influence. However, an alternative suggestion is that while the ethnicity of a candidate may have some effect on voter behaviour, in the long-run, their competence and job performance was the most important factor (Stein, 2005).

A similarly complex setting has been found in New Zealand: according to one study, Māori voters were more likely to vote for candidates who also identified themselves as Māori (Banducci, Donovan, \& Karp, 2004).

There are other factors to take into account, for the significance that Asian members of Parliament have in political studies is clearly not limited to just the relationship they have with their corresponding ethnic communities. Another obvious factor is the effect minority candidates have on voters of the general population. It is also worth considering in future studies how a non-Asian voter perceives and regards an Asian candidate, whether they believe they can be satisfactorily represented by them - and whether other political actors 
such as party officials share these views. While possibly indicating the anticipated intolerance of New Zealand voters for an Asian candidate, an article published in a newsmagazine a few years before Pansy Wong's appointment to Cabinet remarked: “A National Party source says that it is unlikely that [Wong] will rise any further in the party because of concerns that her accent will alienate non-Asian voters" $(\mathrm{Ng}, 2005)$.

These points all illustrate the complex relationship between ethnicity, voting and politics. Beyond political representation, there are other areas of public policy and civic life that the growth of New Zealand's Asian population has implications for, as Andrew Butcher (2010) points out: “[There are] challenges to [the country]'s bicultural framework... social policy, how we measure and understand ethnicity and issues of national identity" (p. 137).

\footnotetext{
"Across all spheres of policy - justice, welfare, health, tax, the labour market, immigration, education, retirement - an increase in Asian populations could place a strain on systems that: (a) are largely well-equipped for the needs of European, Māori and Pacific peoples, but not necessarily for Asian peoples and (b) are based on assumptions about an individual's adherence to a particular rule of law, understanding of judicial and political processes, health needs and previous experiences of health-care, prior educational knowledge, and expectations around retirement age, savings and where people may live in retirement" (p. 144).
}

This sentiment has been echoed by other researchers, including Augie Fleras and Paul Spoonley (1999), who said as early as more than a decade ago that: "[New Zealand] needs to [re-think] its core institutions and values in a way that encompasses the pluralistic nature of contemporary New Zealand" (p. 252).

In many ways, the findings of this thesis appear to highlight more questions that need to be asked than that it answers. This indicates the size of the subject at hand, that minority representation does not exist in a vacuum but in the context of other theories, issues and matters in political studies. 


\section{Chapter VIII: Conclusion}

This thesis has found the difficulty in conclusively determining the role of New Zealand Asian members of Parliament. This finding is a reflection of the difficulty of defining representation itself; as a multitude of scholars, authors and researchers have determined over centuries, political representation is complex with numerous different aspects.

The role of New Zealand's Asian members of Parliament, however varied, must also include that of pioneer. In her valedictory statement before retiring from politics, the first of those members - Pansy Wong (2010) - summarised her experience:

\footnotetext{
"It was beyond my wildest dreams when 14 years ago, in 1996, a girl born in Shanghai, China, who grew up in a Hong Kong apartment where eight families shared a single kitchen and bathroom, delivered her historic maiden speech as New Zealand's first member of Parliament of Asian ethnicity. That dream is not mine alone, and it comes with expectation, responsibility, and hope. I have tried every single day to keep that dream alive."
}

Wong said she believed her political career was proof "that my country is a land of equal opportunity, and that Asian New Zealanders can succeed in the highest office." As she left, she said "the journey had been remarkable [...] Nowadays, it is accepted that ethnic New Zealanders can and will become parliamentarians."

Looking forward, the interview participants conveyed optimism for the representation of New Zealand's Asian population, commenting: "[The country] is growing more and more diverse. More of our ethnic communities... They're born here. They think of themselves as New Zealanders [rather than] as Asians.” This highlights the prospect that as New Zealand grows increasingly diverse, it may become redundant to think of ethnic minority politicians in the context of representing ethnic minorities; individual identities become more complex and expand beyond a shared ethnic background.

This conflicts to a theory posited by one study (Carlson, 1984), which states that the amount of attention paid to candidates' images is likely to increase as the trend of party identification continues to decrease - leading to the emergence of candidate ethnicity as an important influence in election outcomes. 
However, other research exists to indicate that with regard to political appointments, precedents such as the election of members of an ethnic minority "may normalise... similar appointments" (Prosky, 2007, p. 31). It is possible to take this to mean that as New Zealand comes to see more and more Asian members in its House of Representatives, that they will be characterised less so as "Asian" members, and increasing as simply members.

One positive conclusion that can be drawn from this thesis, albeit tentatively, is that through the inclusion of more and more different sectors of society, the New Zealand Parliament is expressing a greater acceptance and appreciation of diversity and multiculturalism. This is concurred by other researchers of Asian and political studies in New Zealand, with Andrew Butcher (2010) writing: "Prospective parliamentary candidates are being eagerly courted by the major political parties ahead of the 2011 general election. That, at one level, is a positive effect" (p. 145).

Even if we rely on the accounts provided by interview participants and on the anecdotal evidence they provide that their election has inspired and encouraged members of their ethnic communities, while also fostering positive perceptions for the general population, this is a laudable effect for New Zealand's political narrative and society at large.

This thesis has illustrated through the case study of New Zealand's Asian members that political representation is complex. They do not represent just one ethnic group, or one interest. Their representative role is comprised of multiple and numerous components. They are not one-dimensional, easily circumscribed and finitely defined; and in essence, this is what we can understand representation to be. 


\section{Appendices}

Appendix 1: Definition of the Asian ethnicity by geographic origin

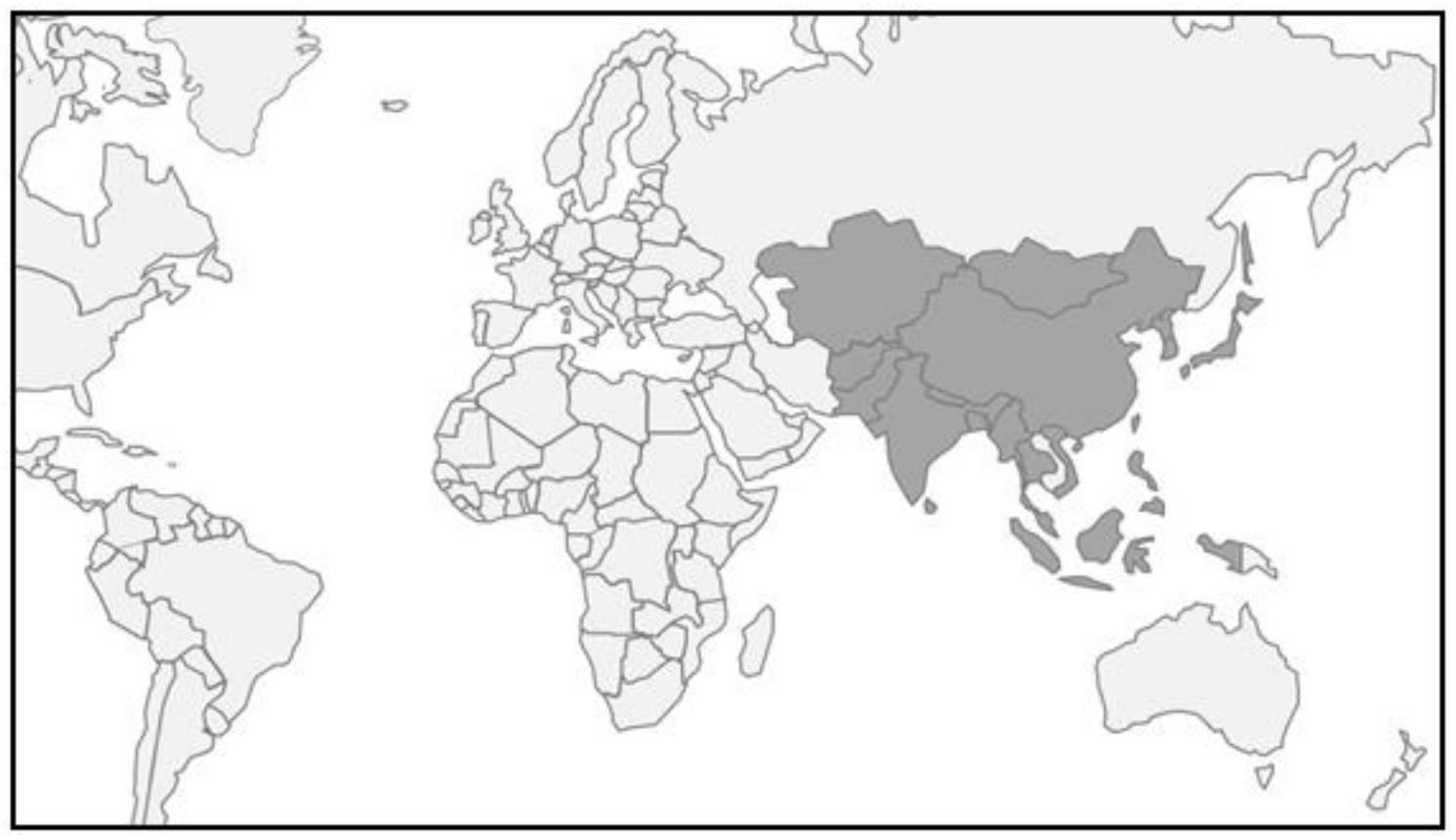

Appendix 2: Growth in New Zealand's Asian population, 1991-2006

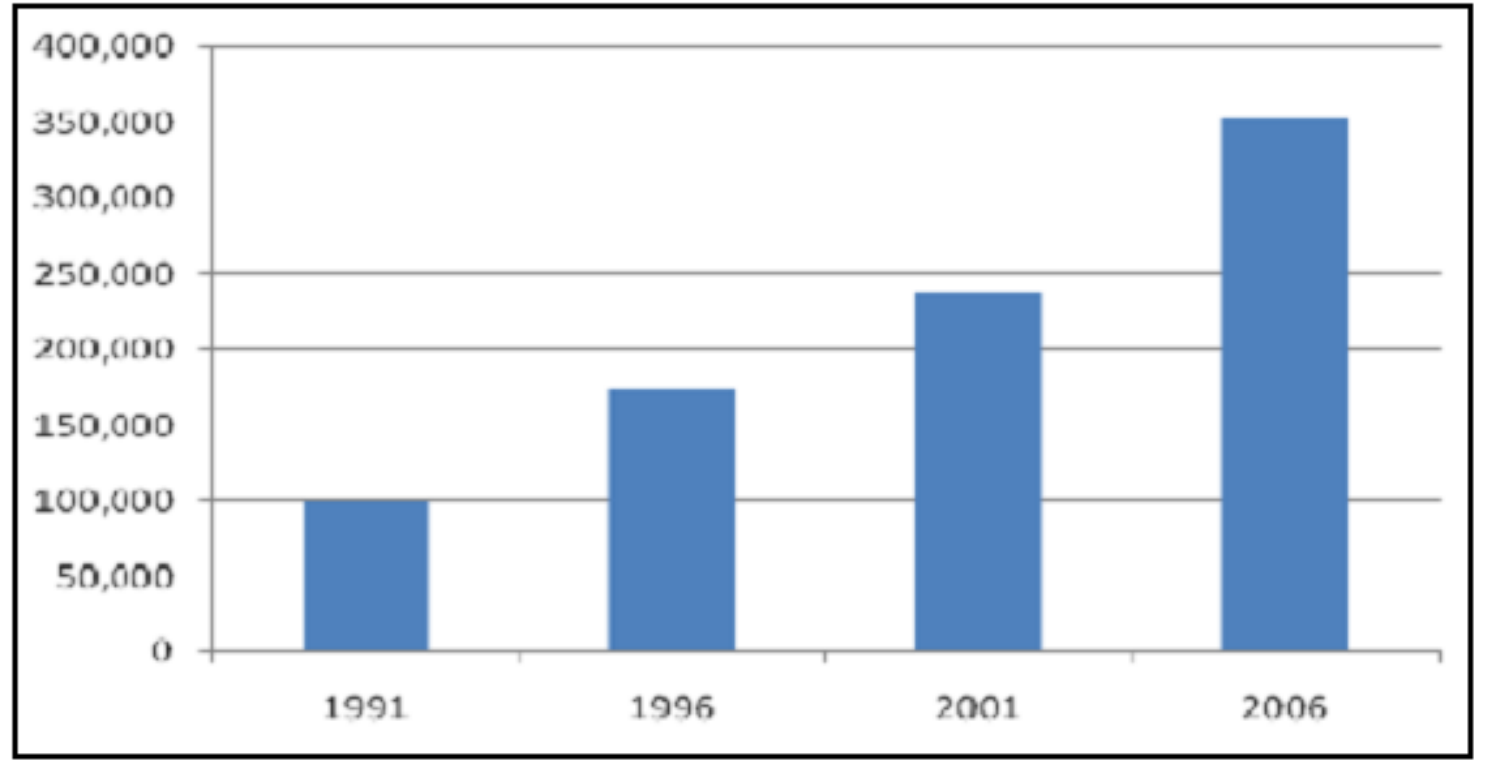

Source: Badkar \& Tuya, 2010, p. 10. 
Appendix 3: Growth in major ethnic groups in New Zealand, 1996-2006

\begin{tabular}{|c|c|c|c|c|c|}
\hline \multirow{2}{*}{ Year } & \multicolumn{4}{|c|}{ Ethnic group } & \multirow{2}{*}{$\begin{array}{c}\text { Total NZ } \\
\text { population }\end{array}$} \\
\hline & European & Māori & Pacific Peoples & Asian & \\
\hline 1996 & $2,879,085$ & 523,374 & 202,236 & 173,502 & $3,618,303$ \\
\hline 2001 & $2,871,432$ & 526,281 & 231,801 & 238,176 & $3,737,280$ \\
\hline 2006 & $2,609,589$ & 565,329 & 265,974 & 354,549 & $4,027,947$ \\
\hline \% change (1996-2006) & $-9.4 \%$ & $8.0 \%$ & $31.5 \%$ & $104.3 \%$ & $11.3 \%$ \\
\hline
\end{tabular}

Source: Badkar \& Tuya, 2010, p. 11

Appendix 4: Members of Parliament identifying as Māori, Pacific peoples or Asian 1984-2008, and Māori, Pacific peoples or Asian share of the total population

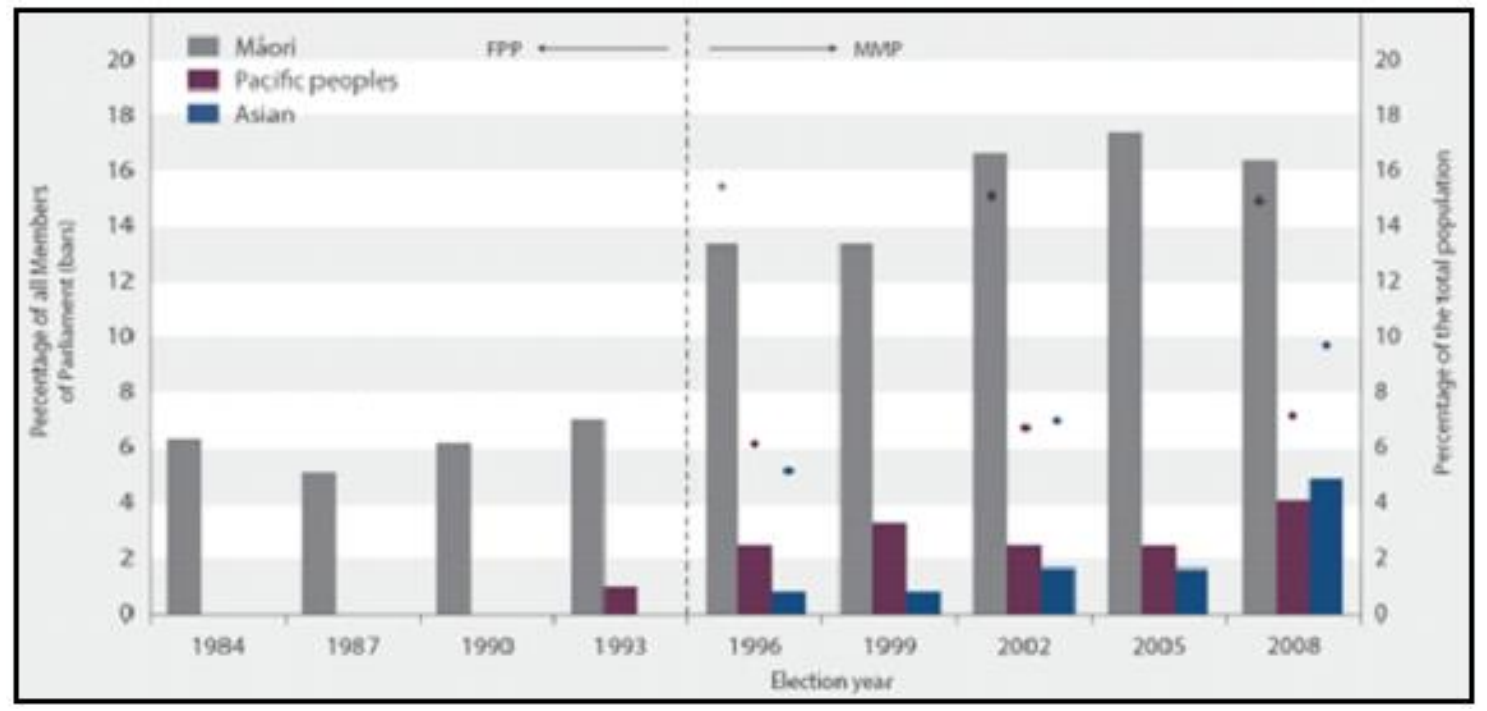

Source: Ministry of Social Development, 2009 


\section{Appendix 5: Electoral Commission on the four alternative voting systems at the 2011 Referendum on the Voting System}

\section{FPP: First-past-the-Post}

There are 120 members of Parliament. Each of the 120 electorates, including the Māori electorates, elects one member. Each voter has one vote to choose the member of Parliament they want to represent the electorate they live in. The candidate who gets the most votes wins. They do not have to get more than half the votes. Large parties - and in particular the winning party - usually win a share of the seats in Parliament larger than their share of all the votes across the country. Smaller parties usually receive a smaller share of seats than their share of all the votes. A government can usually be formed without the need for coalitions or agreements between parties (Electoral Commission, 2013).

\section{PV: Preferential Voting}

With PV there are 120 members of Parliament. Each of the 120 electorates, including the Māori electorates, elects one member of Parliament. Voters rank the candidates - 1, 2, 3, etc - in the order they prefer them. A candidate who gets more than half of all the first preference votes (that is votes marked "1") wins. If no candidate gets more than half the first preference votes, the candidate with the fewest number " 1 " votes is eliminated and their votes go to the candidates each voter ranked next. This process is repeated until one candidate has more than half the votes. Large parties - and in particular the winning party - usually win a share of the seats in Parliament larger than their nationwide share of the first preference votes. It is hard for smaller parties to win seats in Parliament, but votes for smaller party candidates may influence who wins the seat because of second, third, etc preferences. A government can usually be formed without the need for coalitions or agreements between parties. (Electoral Commission, 2013a).

\section{STV: Single Transferable Vote}

There are 120 members of Parliament. Each electorate has more than one member. This includes the Māori electorates. It is likely the 120 members would be divided between 24 and 30 electorates, each with 3 to 7 members. Each voter has a single vote that is transferable. Voters either rank the individual candidates $-1,2,3$, etc - in the order they 
prefer from all the candidates, or they may vote for the order of preference published in advance by the political party of their choice. Members are elected by receiving a minimum number of votes. This is known as the quota and is based on the number of votes in each electorate and the number of members to be elected. Candidates who reach the quota from first preference votes are elected. If there are still electorate seats to fill, a twostep process follows. First, votes the elected candidates received beyond the quota are transferred to the candidates ranked next on those votes. Candidates who then reach the quota are elected. Second, if there are still electorate seats to fill, the lowest polling candidate is eliminated and their votes are transferred to the candidates ranked next on those votes. This two-step process is repeated until all the seats are filled. The number of MPs elected from each political party roughly mirrors the party's share of all the first preference votes across the country. Coalitions or agreements between political parties are usually needed before governments can be formed. (Electoral Commission, 2013b).

\section{SM: Supplementary Member}

There are 120 Members of Parliament. There are 90 electorates, including the Māori electorates. Each elects one member, called an electorate member of Parliament. The other 30 seats are called supplementary seats. Members are elected to these seats from political party lists and are likely to be called list members of Parliament. Each voter gets two votes. The first vote is to choose the member the voter wants to represent the electorate they live in. This is called the electorate vote. The candidate who gets the most votes wins. They do not have to get more than half the votes. The second vote is for the political party the voter chooses. This is called the party vote. The share of the 30 supplementary seats each party gets reflects its share of the party vote. For example, if a party gets 30 per cent of the party vote, it will get about nine list members in Parliament (being 30 per cent of the 30 supplementary seats) no matter how many electorate seats it wins. This makes SM different from MMP where a party's share of all 120 seats mirrors its share of the party vote. Under SM, one or other of the major parties would usually have enough seats to govern alone, but coalitions or agreements between parties may sometimes be needed. (Electoral Commission, 2013c). 


\section{Appendix 6: Interview information provided to participants}

[DATE]

[NAME]

[ADDRESS LINE 1]

[ADDRESS LINE 2]

[ADDRESS LINE 3]

\section{Dear [NAME]}

I am a Masters student in Political Science at Victoria University of Wellington. As per the requirements of this degree, I am undertaking a research project that will consider the theoretical concept of "fair" political representation and analyse the selection and election of New Zealand's Asian Members of Parliament under the Mixed Member Proportional electoral system.

The political representation of the country's Asian population is a relatively recent development and it is an understudied area in both New Zealand political science and Asian studies. Consequently, I hope that my research, once complete, will make a significant contribution in developing this emerging field of study.

Given the limited number of existing academic works in this field, my project will depend heavily on information obtained from interviews. I therefore ask for your participation as an individual whose personal experiences, knowledge and perspectives would be highly relevant and similarly most appreciated.

Please find enclosed a participant information sheet and a consent form, which provide further detail about the interview process. I am available to answer any questions or to discuss my research at greater length with you if you require.

If you wish to participate in this project, the signed consent form can be returned to me at the contact details provided, and a copy will be made available to you for your records. Following its receipt, it is anticipated that the interview would take place at a time and venue of mutual convenience. Alternatively, if you are able to provide an email acknowledgement of this letter I am able to provide the consent form at the time of the interview.

Yours sincerely

Seonah Choi

Encl. 


\title{
PARTICIPANT INFORMATION SHEET FOR A STUDY OF THE SELECTION AND ELECTION OF NEW ZEALAND'S ASIAN MEMBERS OF PARLIAMENT UNDER MMP
}

\author{
RESEARCHER: Seonah Choi, School of History, Philosophy, Political Science and \\ International Relations, Victoria University of Wellington
}

I am a Masters student in Political Science at Victoria University of Wellington. As per the requirements of this degree, I am undertaking a research project that will consider the theoretical concept of "fair" political representation and analyse the selection and election of New Zealand's Asian Members of Parliament under the Mixed Member Proportional system. Upon its completion, this project will take the form of a thesis.

As part of my research, I am seeking to undertake interviews with a number of selected individuals, and as an individual whose experience, knowledge and perspective would be highly relevant to this subject, your agreement to participate in this project would be appreciated. In adherence of University policy, this project has approval from the Ethics Committee.

It is anticipated that the interview will take place in person at a pre-determined time. Alternatively, if this arrangement is not possible, a telephone or written interview could be considered. The interview is expected to last approximately one hour, during which time you will be invited to discuss aspects of your current position (or former, where relevant) based on the questions identified in the enclosed attachment.

The interviews will be digitally recorded and you will be provided with both an electronic copy and the resulting transcript upon which the findings of this project will be based. Once the project is complete, this data will be destroyed within two years.

The responses you provide will be placed into a written report. As provided in the enclosed consent form, you have the option of choosing to be identified in your responses, or to remain anonymous. It is recognised that individuals could be identified by way of deduction if one or more participants decide that their responses can be attributed to them by name. Therefore, if any one participant requests to remain anonymous, all other participants will be accorded the same treatment. In this case, it will not be possible for any participant to be identified personally.

All the material that is collected will be kept confidential and no individual, excepting myself and my project supervisors, Emeritus Professor Margaret Clark and Professor Stephen Levine, will have access to the recordings or the transcripts of the interviews. Once this project is complete, the resulting thesis will be submitted for assessment to the School of History, Philosophy, Political Science and International Relations at the University and later deposited in the University library.

Should any participants decide to withdraw from the project, they may do so at any time up to two weeks after the interview takes place, and any information provided prior to this will be disposed of. 
Further, I am happy to provide you with a copy of the completed project if you wish.

If you have any questions or require further information about this research project, my contact details are as follows:
[ADDRESS LINE 1]
[ADDRESS LINE 2]
[ADDRESS LINE 3]
[CONTACT NUMBER]
[CONTACT EMAIL]

Alternatively, the contact details of my co-supervisors for this project are as follows:

\author{
Emeritus Professor Margaret Clark \\ School of History, Philosophy, Political Science and International Relations \\ Victoria University of Wellington \\ PO Box 600 \\ Wellington \\ margaret.clark@vuw.ac.nz \\ Professor Stephen Levine \\ School of History, Philosophy, Political Science and International Relations \\ Victoria University of Wellington \\ PO Box 600 \\ Wellington \\ stephen.levine@vuw.ac.nz
}




\title{
CONSENT TO PARTICIPATION IN RESEARCH
}

\author{
'The Politics of Presence: The Selection and Selection of New \\ Zealand's Asian Members of Parliament under MMP' \\ Seonah Choi, School of History, Philosophy, Political Science and \\ International Relations
}

Please indicate your approval to the following statements:

$\square \quad$ I have been provided with adequate information pertaining to the nature and objectives of this research project, which I have understood. I have been provided with an opportunity to seek further clarification and/or explanation and consequently, I give my consent to participate in this research;

$\square \quad$ I consent to information or opinions which I have given being attributed to me in any reports on this research; or

$\square \quad$ I understand that any information or opinions I provide will be kept confidential and utilised only in a non-attributable form;

$\square \quad$ I understand that I have the option of not answering questions during the interview;

$\square \quad$ I understand that I will be provided with a tape recording of my interview and an opportunity to check any resulting transcripts, upon which any part of this research project may be based;

$\square \quad$ I understand that the information I provide will be used only for this research project and that any further use will require my written consent;

$\square \quad$ I understand that I may withdraw from participating in this research project at any time before the interview takes place without penalty, and that any information provided prior to this will be disposed of;

$\square \quad$ I would like to receive a copy of the results of this research project upon its completion (If ticking this box, please provide your address on this consent form).

Signed

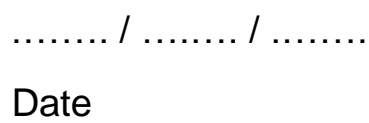

Name of participant (please print) 


\section{Appendix 7: Interview sample questions}

\section{SAMPLE QUESTIONS FOR DISCUSSION}

1. Introductory / Personal Background

- What do you think is the primary function of a MP?

- What was your background prior to entering Parliament? Have you always been interested in politics, or in becoming a politician?

- What personal traits do you think qualified you to become a MP?

- Is your ethnicity a significant part of your identity? If so, why? If not, why?

2. Candidacy

- How did you enter politics? What prompted you to seek candidacy?

- Tell me about the competition you faced from other hopeful candidates.

- Why do you think you were selected as a candidate?

- How big a factor do you believe your ethnicity was in your candidacy?

- What is your opinion on your party's candidate selection processes?

- What is your opinion on your party's list ranking processes?

3. Campaigning

- Tell me about your campaigning experience. During the campaign period, do you have much autonomy in how and where you campaign?

- Do you deliberately seek to gain votes from particular groups? If so, which ones and why?

- Do you think your ethnicity is an advantage or a disadvantage when campaigning? Why?

4. In Parliament

- What do you regard as your role in Parliament?

- What issues do you feel most strongly about? Why?

- As a MP, what do you regard as your biggest accomplishment to date?

- How big a factor is your ethnicity as a MP?

- Do you regard yourself as a spokesperson for any group? If so, which one/s and why?

- In becoming a MP, what has been the response from your minority community? Do you believe they have any expectations of you as a representative?

- Are you conscious of being a member of a minority, both in caucus and in Parliament?

- How is your relationship with other members of Parliament, including the party leadership?

- How do you think you are perceived by other members of Parliament, including the party leadership?

- How do you think you are perceived by the voting public?

- How do you think you are perceived by your minority community?

- Are you satisfied with your role and position in caucus and in Parliament?

5. MMP

- What is your opinion on the mixed member proportional (MMP) electoral system? 
- How significant a factor do you think MMP was in your selection and election into Parliament? Do you think you would have entered Parliament under a different electoral system?

6. Prospects

- What do you hope to accomplish as a member of Parliament? 


\section{Bibliography}

Abney, G. F., \& Hutchinson, J. D. (1981). Race, Representation and Trust: Changes in Attitudes After the Election of a Black Mayor. Public Opinion Quarterly, 45(1), 91101.

ACT Party. (2005). ACT releases its Party List for 2005 election. Retrieved 5 July, 2013, from http://www.act.org.nz/news/act-releases-its-party-list-for-2005-election

Adams, J. (1776). Thoughts on Government. In G. A. Peel (Ed.), The Political Writings of John Adams (pp. 83-92). Indianapolis: Hackett Publishing Company.

Asia New Zealand Foundation. (n.d.). Raymond Huo. Asia New Zealand Foundation. Retrieved 3 March, 2014, from http://www.asianz.org.nz/about-us/ourpeople/patron-and-board-trustees/huo

Badkar, J., \& Tuya, C. (2010). The Asian Workforce: A Critical Part of New Zealand's Current and Future Labour Market. Wellington: New Zealand Department of Labour.

Bakshi, K. S. (2010). Profile. Retrieved 5 July, 2013, from http://www.bakshi.co.nz/index.php?/pages/profile.html

Banducci, S. A., Donovan, T., \& Karp, J. A. (2004). Minority Representation, Empowerment, and Participation. The Journal of Politics, 66(2), 534-556.

Beaglehole, A. (2012). Immigration regulation - 1986-2003: selection on personal merit. Te Ara - the Encyclopedia of New Zealand Retrieved 5 June, 2012, from http://www.teara.govt.nz/en/immigration-regulation/page-5

Bird, K., Saalfeld, T., \& Wüst, A. M. (2011). Ethnic Diversity, Political Participation and Representation: A Theoretical Framework. In K. Bird, T. Saalfeld \& A. M. Wüst (Eds.), The Political Representation of Immigrants and Minorities: Voters, Parties and Parliaments in Liberal Democracies (pp. 1-22). New York: Routledge.

Blackwell, C. W. (2003). Athenian Democracy: A Brief Overview. Athenian Law in its Democratic Context. Retrieved 7 September, 2013, from http://www.stoa.org/projects/demos/article_democracy_overview?page=5\&greekE ncoding=

Boston, J., Levine, S., McLeay, E., \& Roberts, N. S. (1996). New Zealand Under MMP: A New Politics? Auckland: University of Auckland Press with Bridget Williams Books.

Branton, R. P. (2009). The Importance of Race and Ethnicity in Congressional Primary Elections. Political Research Quarterly, 62(3), 459-473.

Burke, E. (1854). The Works of the Right Honourable Edmund Burke (Vol. 1). London: Henry G. Bohn.

Butcher, A. (2010). Demography, Diaspora and Diplomacy: New Zealand's Asian Challenges. New Zealand Population Review(36), 136-157.

Carlson, J. M. (1984). The Impact of Ethnicity on Candidate Image. Polity, 16(4), 667672.

Caton, H. (2001). Demos. In P. B. Clarke \& J. Foweraker (Eds.), Encyclopedia of Democratic Thought (pp. 268-271). London: Routledge.

Chapman, K. (2011, 4 September). National announce party list. Stuff. Retrieved from http://www.stuff.co.nz/national/politics/5561512/National-announce-party-list

Cheng, D. (2010, 14 December). Pansy Wong resigns as MP. New Zealand Herald. Retrieved from http://www.nzherald.co.nz/nz/news/article.cfm?c_id=1\&objectid=10694214

Cheng, D. (2014, 13 July). ACT release party list. NZ Herald. Retrieved from http://www.nzherald.co.nz/nz/news/article.cfm?c_id=1\&objectid=11292767 
Chief Electoral Office. (1996). Party Lists of Successful Registered Parties. New Zealand Ministry of Justice. Retrieved 3 March, 2014, from http://www.electionresults.govt.nz/electionresults_1996/pdf/3.3\%20Party\%20Lists \%20of\%20Successful\%20Registered\%20Parties.pdf

Chief Electoral Office. (1999). Party Lists of Successful Registered Parties. New Zealand Ministry of Justice. Retrieved 3 March, 2014, from http://www.electionresults.govt.nz/electionresults_1999/e9/html/e9_partIII_1.html

Chief Electoral Office. (2002). Party Lists of Successful Registered Parties. New Zealand Ministry of Justice. Retrieved 3 March, 2014, from http://www.electionresults.govt.nz/electionresults_2002/e9/html/e9_part3.html

Chief Electoral Office. (2005). Party Lists of Successful Registered Parties. New Zealand Ministry of Justice. Retrieved 3 March, 2014, from http://www.electionresults.govt.nz/electionresults_2005/e9/html/e9_part3_1.html

Chief Electoral Office. (2008). Party Lists of Successful Registered Parties. New Zealand Ministry of Justice. Retrieved 3 March, 2014, from http://www.electionresults.govt.nz/electionresults_2008/e9/html/e9_part3_1.html

Chief Electoral Office. (2011). National Party List 2011. Retrieved 3 March, 2014, from http://www.elections.org.nz/events/past-events-0/2011-general-election/partiescandidates-and-promoters-2011-general-election--2

Choudhary, A. (2012, 31 January). Pakistani blood donors do us proud. Indian Newslink. Retrieved from http://www.indiannewslink.co.nz/index.php/archives2012/feb_1_2012_issue/pakist ani-blood-donors-do-us-proud.html

Colleau, S. M., Glynn, K., Lybrand, S., Merelman, R. M., Mohan, P., \& Wall, J. E. (1990). Racism in Candidate Evaluation. Political Behavior, 12(4), 385-402.

Commerce Committee. (2005). 2005/6 Estimates Vote Commerce. Report of the Commerce Select Committee - New Zealand House of Representatives. Retrieved 6 October, 2012, from http://www.parliament.nz/NR/rdonlyres/C04EDD40-EB774279-A639-B1CB1861794E/15064/DBSCH_SCR 3176_3195.pdf

Cornwell, E. (1980). Ethnic Group Representation: The Case of the Portuguese. Polity, 13(1), 5-20.

Dastgheib, S. (2014, 15 April). Kenneth Wang elected ACT deputy leader. Stuff. Retrieved from http://www.stuff.co.nz/national/politics/9944101/Kenneth-Wangelected-Act-deputy-leader

DeAngelis, T. (2009). What will Obama's election mean for race relations in America? Monitor on Psychology, 40.

Dovi, S. (2011). Political Representation. The Stanford Encyclopedia of Philosophy. Retrieved 28 March, 2013, from http://plato.stanford.edu/archives/win2011/entries/political-representation

Eccleshall, R., Geoghegan, V., Jay, R., \& Wilford, R. (1984). Political Ideologies: An Introduction. Auckland: Hutchinson Group.

Electoral Commission. (2006). From FPP to MMP. Retrieved 6 June, 2012, from http://www.elections.org.nz/voting/mmp/history-mmp.html

Electoral Commission. (2013). FPP: First-past-the-Post. Retrieved 6 June, 2012, from http://www.elections.org.nz/events/past-events-0/2011-referendum-votingsystem/about-referendum-choices/fpp-first-past-post

Electoral Commission. (2013a). PV: Preferential Voting. Retrieved 6 June, 2012, from http://www.elections.org.nz/events/past-events-0/2011-referendum-votingsystem/about-referendum-choices/pv-preferential-voting 
Electoral Commission. (2013b). STV: Single Transferable Vote. Retrieved 6 June, 2012, http://www.elections.org.nz/events/past-events-0/2011-referendum-votingsystem/about-referendum-choices/stv-single-transferable

Electoral Commission. (2013c). SM: Supplementary Member. Retrieved 6 June, 2012, from http://www.elections.org.nz/events/past-events-0/2011-referendum-votingsystem/about-referendum-choices/sm-supplementary-member

Fleras, A., \& Spoonley, P. (1999). Recalling Aotearoa: Indigenous Politics and Ethnic Relationship in New Zealand. Auckland: Oxford University Press.

France, T. (2014). Appo Hocton - New Zealand's First Chinese Immigrant. Retrieved 16 July, 2013, from http://nzchinasociety.org.nz/14631/appo-hocton-new-zealandsfirst-chinese-immigrant/

Gallup Organization. (2008). Americans see Obama election as milestone (Graphs). The Guardian. Retrieved from http://www.gallup.com/poll/111817/americans-seeobama-election-race-relations-milestone.aspx

Gay, C. (2002). Spirals of Trust? The Effect of Descriptive Representation on the Relationship Between Citizens and Their Government. American Journal of Political Science, 46(4), 717-733.

Griffin, J. \& Keane, M. (2006). Descriptive Representation and the Composition of African American Turnout. American Journal of Political Science, 50(4), 9981012.

Grigg, J. (1998). Dr Rajen Prasad - Chief Commissioner, Families Commission. For A Change. Retrieved 2 February, 2014, from http://www.nriinternet.com/NRIpoliticians/ASIA/New_Zealand/A_Z/P/Rajindra_P arsad/index.htm

Haider-Markel, D., Joslyn, M., \& Kniss, C. (2000). Minority Group Interests and Political Representation: Gay Elected Officials in the Policy Process. The Journal of Politics, 62(2), 568-577.

Hamilton, A., Madison, J., \& Jay, J. (1788). The Federalist Papers. New York: New American Library.

Health, M. o. (2012). Asian and migrant health. Retrieved 7 June, 2012, from http://www.health.govt.nz/our-work/populations/asian-and-migrant-health

Herald staff. (2008a, 31 August). Surprise picks in Labour Party list. New Zealand Herald. Retrieved from http://www.nzherald.co.nz/nz/news/article.cfm?c_id=1\&objectid=10529901

Herald staff. (2008b, 17 November). Wong becomes NZ's first Asian minister. New Zealand Herald. Retrieved from http://www.nzherald.co.nz/nz/news/article.cfm?c id=1\&objectid=10543514

Hewitson, M. (2007, 29 September). Don't ever call Pansy bossy. New Zealand Herald. Retrieved from http://www.nzherald.co.nz/politics/news/article.cfm?c_id=280\&objectid=1046655 $\underline{8}$

Hobbes, T. (1651). Leviathan (1996 ed.). Cambridge: Cambridge University Press.

Holt, J. C. (1974). A Vernacular-French Text of Magna Carta 1215. English Historical Review, 89, 364-364.

Howard, A. E. D. (1998). Magna Carta: Text and Commentary (2nd ed.): University of Virginia Press.

Independence Hall Association. (2014). Common Sense by Thomas Paine. US

History.org. Retrieved 3 March, 2014, from

http://www.ushistory.org/paine/commonsense/ 
Ip, M. (2012a). Chinese: The first immigrants. Te Ara - the Encyclopedia of New Zealand Retrieved 5 June, 2012, from http://www.teara.govt.nz/en/chinese/page-2

Ip, M. (2012b). Later Settlement. Te Ara - the Encyclopedia of New Zealand Retrieved 5 June, 2012, from http://www.teara.govt.nz/en/chinese/page-3

Ip, M. (2012c). Post-war Changes. Te Ara - the Encyclopedia of New Zealand Retrieved 5 June, 2012, from http://www.teara.govt.nz/en/chinese/page-4

Kakubayashi, M., \& Ginestet, A. (2009, 15 April). Scoop's 'Meet the MPs' Project:

Raymond Huo. Scoop. Retrieved from http://www.scoop.co.nz/stories/HL0910/S00028.htm

Kirk, J. (2008). National's list promotes strength and diversity. New Zealand National Party. Retrieved 3 March, 2014, from http://www.national.org.nz/article.aspx?articleid=28388

Lien, P. (2004). Asian-Americans and Voting Participation: Comparing Racial and Ethnic Differences in Recent U.S. Elections. International Migration Review, 38(2), 493517.

Locke, J. (1689). Two Treatises on Government (1947 ed.). New York: Hafner Press.

MacAskill, E. (2008). US election: Obama accused of playing race card as presidential campaign turns nasty. The Guardian. Retrieved from http://www.guardian.co.uk/world/2008/aug/01/barackobama.uselections2008

Mansbridge, J. (1999). Should Blacks Represent Blacks and Women Represent Women? A Contingent "Yes". Journal of Politics, 61, 628-657.

McGee, D. (2005). Parliamentary Practice in New Zealand (3rd ed.). Wellington: Dunmore Publishing.

McLeay, E. (2000). The New Parliament. In J. Boston, S. Church, S. Levine, E. McLeay \& N. S. Roberts (Eds.), Left Turn: The New Zealand General Election of 2000 (pp. 203-216). Wellington: Victoria University Press.

McRobie, A. (1993). The Electoral Referendum: Issues and Options. In A. McRobie (Ed.), Taking it to the People? The New Zealand Electoral Reform Debate (pp. 24-40). Christchurch: Hazard Press.

Mezey, M. L. (2008). Representative Democracy: Legislators and Their Constituents. Plymouth: Rowman and Littlefield Publishers, Inc.

Mill, J. S. (1861). Considerations on Representative Government. London: Parler, Son, and Bourn.

Miller, J. C. (1943). Origins of the American Revolution. London: Little, Brown \& Company.

Miller, R. (2004). Who Stood for Office, and Why? In P. A. J. Vowles, S. Banducci, J. Karp \& R. Miller (Ed.), Voters' Veto: The 2002 Election in New Zealand and the Consolidation Minority Government (pp. 85-103). Auckland: Auckland University Press.

Ministry of Social Development. (2009). The Social Report 2009. Retrieved 5 June, 2012, from http://www.socialreport.msd.govt.nz/civil-politicalrights/representation-ethnic-groups-government.html

Moskowitz, D., \& Stroh, P. (1994). Psychological Sources of Electoral Racism. Political Psychology, 15(2), 307-329.

Napier, L. (2009, 15 April). Scoop's 'Meet the MPs' Project: Rajen Prasad. Scoop. Retrieved from http://www.scoop.co.nz/stories/HL0910/S00120.htm

Nelson Mail staff. (2008, 30 October). Smith leads by 36 points: poll. Nelson Mail. Retrieved from http://www.stuff.co.nz/nelson-mail/news/696490 
New Zealand Government. (2011). Parliamentary private secretaries appointed. Retrieved 2 February, 2014, from https://www.national.org.nz/news/news/mediareleases/detail/2011/12/20/parliamentary-private-secretaries-appointed

New Zealand Labour Party. (2005). Talented Kiwis dominated Labour list. Retrieved 3 March, 2014, from http://www.scoop.co.nz/stories/PA0808/S00518.htm

New Zealand Labour Party. (2008). Labour Party list for 2008 election announced. Retrieved 3 March, 2014, from http://www.scoop.co.nz/stories/PA0808/S00518.htm

New Zealand Labour Party. (2011). Labour Party List 2011. Retrieved 3 March, 2014, from https://www.labour.org.nz/sites/default/files/labour-party-list-2011.pdf

New Zealand Labour Party. (2014). Raymond Huo. Retrieved 3 March, 2014, from http://campaign.labour.org.nz/raymond_huo

New Zealand National Party. (2011). National Party releases 2011 party list. Retrieved 5 July, 2014, from https://www.national.org.nz/news/news/mediareleases/detail/2011/09/03/national-party-releases-2011-party-list

New Zealand National Party. (2013a). Kanwaljit Singh Bakshi. Retrieved 5 July, 2014, from https://www.national.org.nz/team/mps/detail/kanwaljit\%20singh.bakshi

New Zealand National Party. (2013b). Melissa Lee. Retrieved 5 July, 2014, from https://www.national.org.nz/team/mps/detail/melissa.lee

Ng, K. (2005). Asian Vote. The Listener. Retrieved 1 February, 2014, from http://www.listener.co.nz/issue/3406/features/4538/asian_vote.html

Pakistan Institute of Legislative Development and Transparency. (2004). Discussion with Dr Ashraf Choudhary. Retrieved 3 March, 2014, from http://www.pildat.org/eventsdel.asp?detid=65

Park, S. J. (2006). Political Participation of "Asian" New Zealanders: A Case Study of Ethnic Chinese and Korean New Zealanders. University of Auckland, Auckland.

Parliamentary Library. (2005). Final results 2005 general election. New Zealand Parliament. Retrieved 2 February, 2014, from http://www.parliament.nz/enNZ/ParlSupport/ResearchPapers/4/0/b/40bcd378849e4ff59302bdc5d2f2fe02.htm

Parliamentary Library. (2009). Manukau East: Electoral Profile. New Zealand Parliament. Retrieved 2 February, 2014, from http://www.parliament.nz/enNZ/MPP/Electorates/EPData/6/1/a/DBHOH_Lib_EP_ManukauEast_Data_3Manukau-East-Electoral-Profile.htm

Parliamentary Library. (2010a). Kanwaljit Singh Bakshi. Retrieved 2 February, 2014, from http://www.parliament.nz/en-NZ/MPP/MPs/MPs/d/3/b/49MP169871-BakshiKanwaljit-Singh.htm

Parliamentary Library. (2010b). Melissa Lee. Retrieved 2 February, 2014, from http://www.parliament.nz/en-NZ/MPP/MPs/MPs/3/3/5/49MP169971-LeeMelissa.htm

Parliamentary Library. (2010c). Rajen Prasad. Retrieved 2 February, 2014, from http://www.parliament.nz/en-NZ/MPP/MPs/MPs/4/1/3/49MP169791-PrasadRajen.htm

Parliamentary Library. (2011a). Former MPs: Ashraf Choudhary. New Zealand Parliament. Retrieved 2 February, 2014, from http://www.parliament.nz/ennz/mpp/mps/former/49PlibMPsFormerAshrafChoudhary1/choudhary-dr-ashraf

Parliamentary Library. (2011b). Former MPs: Hon Pansy Wong. New Zealand Parliament. Retrieved 2 February, 2014, from http://www.parliament.nz/ennz/mpp/mps/former/49PlibMPsFormerPansyWong1/wong-hon-pansy

Parliamentary Library. (2011c). Parliament Voting Systems in New Zealand and the Referendum on MMP. Parliamentary Library research paper Retrieved 2 February, 
2014, from http://www.parliament.nz/resource/ennz/00PLLawRP11031/63a1a37de3ecda41335fe57ace5eb408ae60fa5a

Parliamentary Library. (2012a). Botany: Electoral Profile. New Zealand Parliament.

Retrieved 2 February, 2014, from http://www.parliament.nz/en-

NZ/MPP/Electorates/EPData/2/4/c/DBHOH_Lib_EP_Botany_Data_3-Botany-

Electoral-Profile.htm

Parliamentary Library. (2012b). Electoral Profile Data: Manukau East. New Zealand

Parliament. Retrieved 2 February, 2014, from http://www.parliament.nz/ennz/mpp/electorates/data/DBHOH_Lib_EP_Manukau\%20East_Data_3/manukaueast-electoral-profile\#_64

Parliamentary Library. (2014a). Jian Yang. Retrieved 2 February, 2014, from http://www.parliament.nz/en-nz/mpp/mps/current/50MP202121/yang-jian

Parliamentary Library. (2014b). Rajen Prasad. Retrieved 2 February, 2014, from http://www.parliament.nz/en-nz/mpp/mps/current/50MP169791/prasad-rajen

Parliamentary Library. (2014c). Raymond Huo. Retrieved 2 February, 2014, from http://www.parliament.nz/en-nz/mpp/mps/current/50MP169801/huo-raymond

Pettit, P. (2009). Varieties of Public Representation. In I. Shapiro, S. C. Stokes, E. J. Wood \& A. S. Kirshner (Eds.), Political Representation (pp. 61-89). Cambridge: Cambridge University Press.

Pitkin, H. F. (1967). The Concept of Representation. Berkeley: University of California Press.

Preece, J. J. (2005). Minority Rights. Cambridge: Polity Press.

Prendergast, C. (2000). The Triangle of Representation. New York: Columbia University Press.

Preuhs, R. (2007). Descriptive Representation as a Mechanism to Mitigate Policy Backlash: Latino Incorporation and Welfare Policy in the American States. Political Research Quarterly, 60(2), 277-292.

Prosky, M. (2007). Presidents and Their Minority Cabinet Appointments: Implications for Representation. Unpublished paper presented at the annual meeting of the International Studies Association. Hyatt Regency Chicago and the Sheraton Chicago Hotel and Towers, Chicago, Illinois.

Raman, V. (2012, 14 May). Former MP calls more youngsters to politics. Indian Newslink. Retrieved from http://www.indiannewslink.co.nz/index.php/archives2012/may_15_2012_issue/for mer-mp-calls-more-youngsters-to-politics.html

Rousseau, J.-J. (1762). The Social Contract (1998 ed.). Kent: Wordsmith Editions Limited.

Royal Commission on the Electoral System. (1986). Report of the Royal Commission on the Electoral System: 'Towards a Better Democracy'. Wellington: V. R. Ward, Government Printer.

Runciman, D. (2009). Hobbes's Theory of Representation: Anti-Democratic or ProtoDemocratic? In I. Shapiro, S. C. Stokes, E. J. Wood \& A. S. Kirshner (Eds.), Political Representation (pp. 15-34). Cambridge: Cambridge University Press.

Schwindt-Bayer, L. \& Mishler, W. (2005). An Integrated Model of Women's Representation. The Journal of Politics, 67(2), 407-428.

Skinner, Q. (2005). Hobbes on Representation. European Journal of Philosophy, 13(2), 155-184.

Spoonley, P. (1993). Racism and Ethnicity (2nd ed.). Auckland: Auckland University Press. 
Statistics New Zealand. (2005a). Classification - Ethnicity, Complete. Retrieved 5 June, 2012, from http://www.stats.govt.nz/surveys_and_methods/methods/classifications-andstandards/classification-related-stats-standards/ethnicity.aspx

Statistics New Zealand. (2005b). Ethnicity - Definition. Retrieved 5 June, 2012, from http://www.stats.govt.nz/surveys_and_methods/methods/classifications-andstandards/classification-related-stats-standards/ethnicity/definition.aspx

Statistics New Zealand. (2006). QuickStats about Culture and Identity. Retrieved 5 June, 2012, from http://www.stats.govt.nz/Census/2006CensusHomePage/QuickStats/quickstatsabout-a-subject/culture-and-identity.aspx

Statistics New Zealand. (2010). National Ethnic Population Projections: 2006 (Base) 2026 Update. Retrieved 7 June, 2012, from http://www.stats.govt.nz/methods_and_services/information-releases/nationalethnic-population-projections.aspx

Stein, R. M., Ulbig, S. G., \& Post, S. S. (2005). Voting for Minority Candidates in Multiracial/Multiethnic Communities. Urban Affairs Review, 41, 157-181.

Stuff staff. (2011a, 29 September). Labour, ACT MPs farewell Parliament. Stuff. Retrieved from http://www.stuff.co.nz/national/politics/5707218/Labour-ACTMPs-farewell-Parliament

Stuff staff. (2011b, 10 April). Labour's party list for November election. Stuff. Retrieved from http://www.stuff.co.nz/national/politics/4869855/Labours-party-list-forNovember-election

Swarbrick, N. (2012a). Indians - 1920s to 1930s. Te Ara - the Encyclopedia of New Zealand Retrieved 5 June, 2012, from http://www.teara.govt.nz/en/indians/page-3

Swarbrick, N. (2012b). Indians - Early immigration. Te Ara - the Encyclopedia of New Zealand Retrieved 5 June, 2012, from http://www.teara.govt.nz/en/indians/page-2

Taher, M. (1970). The Asians in Immigrants in New Zealand. In K. W. Thomson \& A. D. Trlin (Eds.). Palmerston North: Massey University.

Tam, W. K. (1995). Asians: A Monolithic Voting Bloc? Political Behavior, 17(2), 223249.

Tan, L. (2008, 17 November). Ethnic candidates begin their pitch. New Zealand Herald. Retrieved from http://www.nzherald.co.nz/nz/news/article.cfm?c_id=1\&objectid=10537951

Terkildsen, N. (1993). When White Voters Evaluate Black Candidates: The Processing Implications of Candidate Skin Color, Prejudice, and Self-Monitoring. American Journal of Political Science, 37(4), 1032-1053.

U.S. National Archives and Records Administration. (n.d.). Magna Carta and Its American Legacy Retrieved 28 July, 2013, from http://www.archives.gov/exhibits/featured_documents/magna_carta/legacy.html

Urbinati, N. (2006). Representative Democracy: Principles and Genealogy. Chicago: University of Chicago Press.

Vance, A. (2014, 2 May). MP Rajen Prasad to retire. Stuff. Retrieved from http://www.stuff.co.nz/national/politics/10001908/MP-Rajen-Prasad-to-retire

Vasil, R., \& Yoon, H. K. (1996). New Zealanders of Asian Origin. Wellington: Institute of Policy Studies, Victoria University of Wellington.

Wang, K. (2008a). Botany voters can't go wrong: Vote Kenneth Wang, get Wang + Wong. Retrieved 4 March, 2012, from http://www.kennethwang.org.nz/E_about_kenneth_2.html 
Wang, K. (2008b). Kenneth Wang Biography. Retrieved 3 March, 2014, from http://www.kennethwang.org.nz/E_about_kenneth_3.html

Wang, K. (2008c). Kenneth Wang Biography in Brief. Retrieved 5 July, 2013, from http://www.kennethwang.org.nz/E_about_kenneth_1.html

Watkins, T., Kay, M., \& Small, V. (2010, 12 November). Pansy Wong resigns Cabinet spot over travel perk. Stuff. Retrieved from http://www.stuff.co.nz/national/politics/4337061/Pansy-Wong-resigns-Cabinetspot-over-travel-perk

Wiessler, D. (2008). Obama says race not an issue. Retrieved 2 March, 2014, from http://www.reuters.com/article/idUSN1931827220080427

Wong, P. (2009). Newsletter: Beyond the glass ceiling. Retrieved 3 March, 2014, from http://www.pansywong.co.nz/post_beyond-the-glass-ceiling_1493_133

Wong, P. (2010). Valedictory statement. Hansard. Vol. 559, p. 16395. New Zealand House of Representatives.

Young, A., \& Oliver, P. (2008, 14 December). New generation to fly party flag at election. New Zealand Herald. Retrieved from http://www.nzherald.co.nz/politics/news/article.cfm?c id=280\&objectid=1052996 $\underline{3}$

Young, S. (1996). National wins the Chinese: Pansy Wong ranked 26 on the List. . Chinese Voice. Retrieved from http://www.stevenyoung.co.nz/The-Chinese-inNew-Zealand/Chinese-Voice/Chinese-Voice-19-September-1996-issue.html

Zimmerman, J. F. (1994). Equity in Representation for Women and Minorities. In W. Rule \& J. F. Zimmerman (Eds.), Electoral Systems in Comparative Perspective: Their Impact on Women and Minorities (pp. 3-14). Westport: Greenwood Press.

Zwetsloot, J. (2009). Melissa Lee - first Korean member in New Zealand's Parliament. Colorado Korean Network. Retrieved 3 March, 2014, from http://www.kncolorado.com/bbs/board.php?bo_table=korea_town_news\&wr_id=6 $\underline{2}$ 